Universidade de Brasília - UnB

Instituto de Ciências Humanas - IH

Departamento de Serviço Social - SER

Disciplina: Trabalho de Conclusão de Curso

Orientador: Professor Doutor Mário Ângelo Silva

\title{
Educação no presídio \\ Uma possibilidade de (re)inserção social do apenado
}

Kaymara Rodrigues Arruda

Matrícula: 03/81942 
"AOS ESFARRAPADOS DO MUNDO E AOS QUE NELES SE DESCOBREM E, ASSIM DESCOBRINDO-SE, COM ELES SOFREM, MAS, SOBRETUDO, COM ELES LUTAM."

Paulo Freire 


\section{RESUMO:}

A presente pesquisa pretende problematizar uma área pouco conhecida e pouco valorizada: a educação no presídio. Atendo-se ao pressuposto de que a educação pode participar como meio de (re)inserção social, foram realizadas entrevistas com educadores que trabalham nos presídios do Distrito Federal e com educandos que já cumpriram a pena de privação de liberdade. Permeado pela contradição, o campo da educação no presídio oferece a possibilidade de (re)inserir o sujeito social, como foi concluído na pesquisa, contudo incorre em seu oposto quando a educação ensejada não se revela ampla, mas uma educação "bancária", educação essa contrária a que Paulo Freire batalhava.

Palavras- chaves: Educação, Emancipação Humana, Cidadania, Inclusão social, política social

\section{ABSTRACT:}

The present research intends to quest and to make some questions about an area little aimed at and little valued: the education in the penitentiary. For that it limits to take care of the conjecture that the education can participate as a way of social reintegration, had been carried through interviews with educators who work in the penitentiary of the Distrito Federal and with students that already had fulfilled the penalty of freedom privation. Crossed with contradiction, the field of the education in the penitentiary offers the possibility of (re) inserting the social being, as it was concluded in the research, however incurs into its opposite when the tried education does not show its amplitude, but "a banking" education, education which is contrary the one that Paulo Freire worked for.

Key Words: Education, Human emancipation, citizenship, social inclusion, social politics 


\section{APRESENTAÇÃO}

O presente trabalho configura requisito para a obtenção de grau de bacharel em Serviço Social e para tanto foi realizado pesquisa na área de interesse da aluna, tendo em vista a atuação na área de estágio. Após realizar estágio no Centro de Desenvolvimento Social de Planaltina, no Projeto "Jovem em Ação", o qual era voltado para jovens em conflito com a lei nasceu o interesse pelos instrumentos utilizados com o objetivo de inserir o ser social, no caso dos jovens em liberdade assistida ${ }^{1}$, a educação.

Após um estudo de viabilidades foi diagnosticado que o campo da educação tem potencial como força de impulso para a integração efetiva do sujeito no convívio social. Essa descoberta motivou o recorte da pesquisa na área prisional, de adultos, em decorrência da real necessidade de um instrumento facilitador para a (re)inserção social dos apenados.

Dessa forma o objeto privilegiado nesse estudo é o papel da educação no processo de (re)inserção social dos sujeitos que cumprem a pena de privação de liberdade. As hipóteses trabalhadas foram confirmadas: a educação formal, servindo à transferência de informação não intenciona a emancipação humana; já a educação que se pretende ampla, que provoca a reflexão crítica, essa possibilita uma transformação social.

Tendo em vista a função de instigar e refletir, essa pesquisa não se pretende concluída, mas antes iniciada, uma vez que problematiza um campo pouco investigado.

\footnotetext{
${ }^{1}$ Liberdade Assistida é uma medida socioeducativa aplicada ao adolescente pela autoridade competente, quando verificada a ocorrência de ato infracional.
} 


\section{SIGLAS}

CDP - Centro de Detenção Provisória

CF - Constituição Federal

CIR - Centro de Internamento e Reeducação

DEPEN - Departamento Penitenciário Nacional

FUNAP - Fundação de Amparo ao Trabalhador Preso

LEP - Lei de Execução Penal

MJ - Ministério da Justiça

ONU - Organização das Nações Unidas

PDF - Penitenciária do Distrito Federal 


\section{SUMÁRIO:}

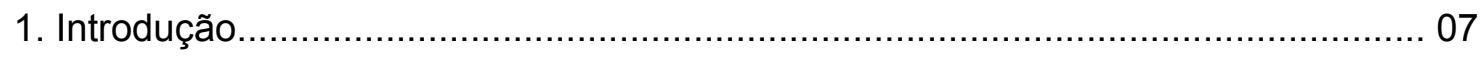

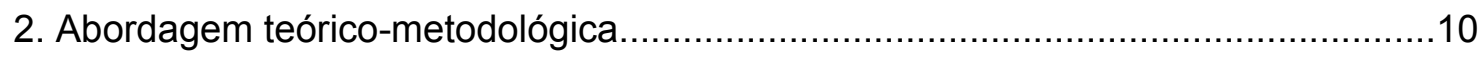

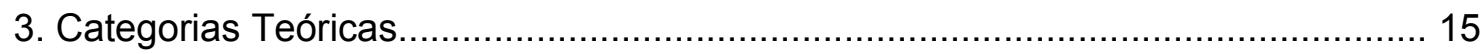

3.1 Questão Social........................................................................... 15

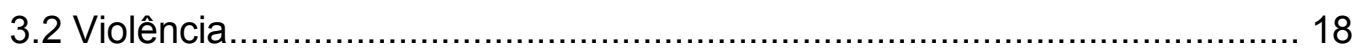

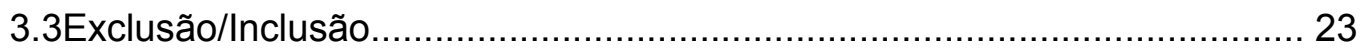

3.4Reclusão/Privação de liberdade....................................................... 25

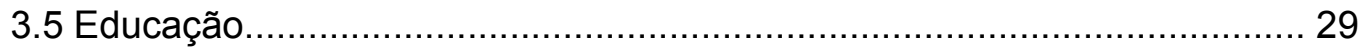

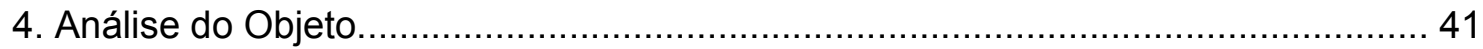

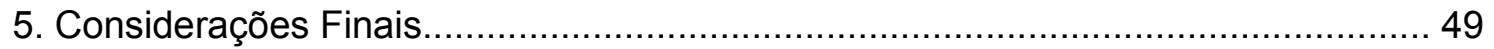

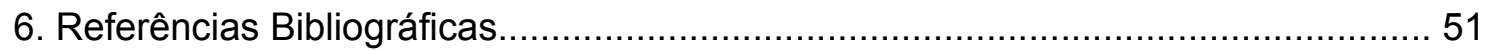

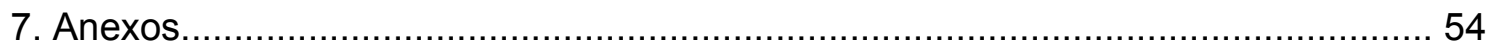

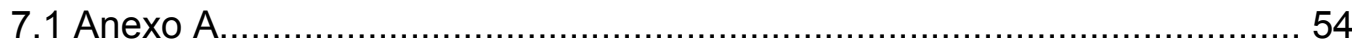

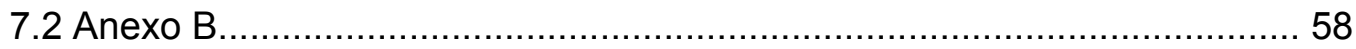

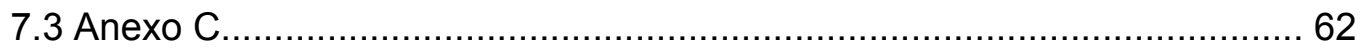




\section{INTRODUÇÃO}

Diante do quadro preocupante em que o sistema prisional brasileiro se insere se faz mister assumir a responsabilidade de buscar mudanças. Questionamentos a respeito do que se pode fazer promovem uma reflexão sobre questões que permeiam a sociedade: o direito, o dever, a cidadania, a educação. A presente pesquisa parte dessa reflexão, buscando a compreensão necessária para se fazer alterações em um sistema carregado pela inépcia e morosidade, e apontado como ineficiente em seu papel de (re)inserir o sujeito à sociedade. O sistema prisional tem vinculado em seu conceito essas características.

Os estabelecimentos penais do país passam por uma crise institucional, política e estrutural, que tem sido protelada, causando agravos nas crises 7 sociais que tanto alarmam a sociedade. O crescimento da população prisional, a falta de vagas, a não adaptação à sociedade, a reincidência no crime, incitam dúvidas sobre a eficácia da privação de liberdade.

A qualidade dos serviços prestados à população carcerária é outro ponto a instigar dúvidas, uma vez que os direitos humanos acirram embates para defender o tratamento justo e decente dos seres humanos. Mesmo tendo esse embate uma tônica poderosa, a realidade dentro dos muros das penitenciárias desacredita um cenário promissor.

Resta então perguntar qual ou quais os caminhos a serem buscados para alterar esse quadro pitoresco. A pesquisa realizada visa traçar uma das alternativas possíveis e humanas de transformar a situação prisional, especificamente no caso dos sujeitos diretamente vinculados ao sistema, os detentos ${ }^{2}$ : por meio da educação.

A legislação que objetiva efetivar as disposições de sentença ou de decisão criminal, Lei $n^{\circ} 7.210 / 84$ (Lei de Execução Penal - LEP), prevê em sua constituição a assistência prestada ao preso e ao internado. Essa assistência se configura em jurídica, material, à saúde, social, religiosa e educacional. Essa última visa proporcionar ao apenado a instrução escolar e a formação profissional.

A inscrição na LEP sobre a assistência educacional se apresenta cerceada de limites. A educação se limita à instrução escolar e/ ou a uma preparação para o trabalho; não objetiva se manifestar mais ampla, de forma a abarcar a conscientização humana. Transforma-se em contradição, pois não busca incitar e incentivar o que o próprio sistema se propõe, ou seja, o retorno ao convívio social. Ao buscar ensinar o básico educativo, a

\footnotetext{
${ }^{2}$ Detento: presidiário em cumprimento de pena. Pena - processo em execução - pós-julgamento e deferimento de sentença.
} 
fim de instruir unicamente, sem atravessar o cerne da reclusão, a reflexão sobre o erro cometido e busca por mudanças pessoais, a educação se manifesta vazia de intenção e de objetivo.

Por esse prisma a pesquisa se fundamenta no processo de (re)inserção social através da educação nos presídios. A reintegração social do apenado é possível apenas com a instrução básica? Que instrução seria essa, para emancipação humana ou mera adaptação ao sistema capitalista?

Essas são questões que amparam na construção do objeto da pesquisa possibilitando montar a estrutura capaz de vislumbrar certos pontos. Nesse cenário social, pouco se tem problematizado a educação como meio de transformação para os que cumprem a pena de privação de liberdade.

A atenção está voltada para o papel duplo da educação: primeiramente em reproduzir a condição de exclusão na medida em que serve à classe dominante; e, segundo, a educação como possibilidade de transformação social a qual intenciona promover a emancipação humana ${ }^{3}$. Parte-se daí duas hipóteses de trabalho, a educação formal, como instrução, como transferência de informações, em que o educando não participa da construção da mesma serve como ilusão de mudança promovida pela classe dominante.

Já a educação que busca no educando o protagonismo para construir a sua própria história, que promove a participação ativa em seu papel cidadão, de inclusão no seio da sociedade é enfraquecida pelos ditames sociais que prevalecem sustentados pela idéia de ordem social. Essa educação para a libertação atua como instrumento de poder de uma classe desprivilegiada instigando uma transformação social.

Visando responder a esses questionamentos esse trabalho se divide em três partes. A primeira parte visa situar os instrumentos de pesquisa que proporcionaram vislumbrar o objeto da melhor forma, tomando a realidade como complexa e, principalmente viva, em constante transformação. No capítulo 1, a preocupação se insere no debate acerca do objeto de pesquisa e dos caminhos tomados objetivando delinear a questão de forma a apresentá-la completamente, dentro do possível.

Apresentado o objeto, busca-se no capítulo seguinte discorrer sobre as categorias que instigaram preocupações, sendo elas participantes da complexa estrutura social que abarca o objeto: a prisão. Dentro desse foco são analisadas as categorias teóricas: questão social, violência, prisão, exclusão/inclusão e educação. Pressupõe que ao

\footnotetext{
${ }^{3} \mathrm{O}$ conceito de emancipação humana utilizado refere-se à liberdade, ou seja, à sua condição de independência e
} autonomia isenta de restrições externas, coações, e de restrições internas, sendo livre para exercer-se como sujeito social. 
analisar a educação no presídio é preciso fundamentar com questões intrínsecas ao próprio objeto relevantes ao sujeito em questão, o educando/interno.

No capítulo seguinte busca-se apresentar o resultado da pesquisa em si, a educação nos presídios do Distrito Federal, tendo em vista uma aproximação da realidade. Apresenta-se a análise da pesquisa, e o tratamento dos dados, orientados pela reflexão sobre o objeto. Busca-se na fala dos próprios educadores a possibilidade de transformação por meio da educação; e a fala dos educandos, que já cumpriram a pena de restrição de liberdade, ou seja, estão livres, complementa e certifica a eficácia dessa educação. 


\section{ABORDAGEM TEÓRICO-METODOLÓGICO}

Por metodologia se entende "o caminho do pensamento e a prática exercida na abordagem da realidade" (MINAYO, 1994). Na metodologia incluem-se as concepções teóricas de abordagem do objeto pesquisado, as técnicas que possibilitam a construção da realidade e o potencial criativo do investigador.

A fim de alcançar os objetivos estabelecidos na pesquisa, pressupostos teóricos e metodológicos foram utilizados para construir a base e o fundamento do trabalho em questão. Para esse estudo, em que o objetivo é solucionar as dúvidas sobre certos fatos, especificamente sobre a educação no contexto de (re)inserção social, a preferência foi dada à pesquisa qualitativa.

As ciências humanas tratam de um objeto complexo, os fatos humanos. Para estudá-los é necessário uma postura menos rígida que a postura dada às ciências naturais, a qual seu objeto de pesquisa são os fatos da natureza, onde a apresentação desses fatos é, muitas vezes mais claro e objetivo, que a apresentação dos fatos humanos.

A pesquisa qualitativa não se faz sem a pesquisa quantitativa, pois "todo fenômeno qualitativo é dotado também e naturalmente de faces quantitativas e viceversa" (DEMO, 2001). Esses dois aspectos da realidade não são dicotomizados, pois são faces diferenciadas de um mesmo fenômeno.

A pesquisa qualitativa só tem a ganhar quando se atém, também, as suas "ilações quantitativas", aliando-se favoravelmente a métodos quantitativos. A fim de não descuidar desse aspecto, os dados obtidos foram devidamente trabalhados, ou seja, as estatísticas receberam o estudo adequado e a atenção devida, seja por sua influência no estudo, seja por sua necessidade para a devida formalização científica.

O problema pesquisado se fundamenta na mobilização para se buscar entendimento sobre alternativas viáveis ao que se propõe na educação no presídio. Em Laville e Dionne (1999), o problema de uma pesquisa é aquilo que mobiliza a mente humana a buscar maior entendimento de questões postas pelo real, ou a busca de soluções para problemas nele existentes, objetivando a sua modificação para melhor.

A construção do problema partiu das indagações a respeito do objetivo da prisão nos dias atuais, após as conquistas dos direitos humanos e a atualização das penas, sendo, portanto, mais dignas e humanas. Indagações a respeito do que se propõe a ser a prisão: apenas punição, ou punição e (re)inserção na sociedade? Se o último, como se 
tem realizado essa (re)inserção, eficaz ou ilusória? Quais os instrumentos utilizados para essa (re)inserção?

Dessa última indagação surgem as assistências previstas em Lei para os detentos, dentre elas a educação. Essas assistências serviriam como meio para objetivar a (re)inserção do sujeito à sociedade, contudo elas tem conseguido alcançar esse objetivo? Especificamente a atenção se concentra na educação, ela tem sido meio de transformação social?

Para responder essas perguntas, executou-se a pesquisa utilizando os princípios e pressupostos da dialética marxista. Para a abordagem do objeto, observaram-se as potencialidades metodológicas da linha marxista, pois "o método crítico-dialético traz uma solução complexa e inovadora do ponto de vista da relação sujeito-objeto: uma perspectiva relacional, que foge ao empirismo positivista e funcionalista e ao idealismo culturalista" (BEHING, BOSCHETTI, 2006).

A análise da educação como resultado de relações complexas e contraditórias que se estabelecem entre os educadores e os educandos, no âmbito dos conflitos que envolvem o sistema prisional, recusa-se a utilização de enfoques unilaterais para explicar suas implicações. Essa relação conturbada se realiza entremeada pelo vigiar e punir do próprio sistema e sua abordagem ainda positivista para com o interno.

Orientada pela linha marxista esse enfoque da educação assume uma configuração mais aproximada da realidade. Não há a pretensão de expor a realidade em sua complexidade, por completa e inteira, pois isso seria impossível. Para a dialética marxista, "o conhecimento é totalizante e a atividade humana, em geral, é um processo de totalização, que nunca alcança uma etapa definitiva e acabada" (KONDER, 1994).

A totalidade é apenas um momento de um processo de totalização. A dialética é a maneira de pensar, elaborada em função da necessidade de reconhecer a constante emergência do novo na realidade, não sendo jamais cristalizada.

Buscou-se na pesquisa explorar as contradições inerentes aos processos sociais dentro do presídio, relacionados ao processo de educação, reconhecendo o limite dessa análise, dada as múltiplas facetas do fenômeno. Sem, contudo cristalizar-se na síntese, que é a visão de conjunto que desvela a estrutura significativa da realidade.

Procura-se situar e analisar o fenômeno social em seu complexo e contraditório processo de produção e reprodução, determinado por várias causas na perspectiva de totalidade. De acordo com Behring e Boschetti (2006), nessa perspectiva, o conhecimento não é absoluto, não se pode deixar enganar pelos aspectos que se apresentam na superfície presente nos fatos, deve-se procurar chegar à essência do fenômeno. 
Pela dialética da totalidade não se pretende conhecer todos os aspectos da realidade. "Na verdade, os fatos expressam um conhecimento da realidade se são compreendidos como fatos de um todo dialético, isto é, determinados e determinantes desse todo, de modo que não podem ser entendidos como fatos isolados" (KOSIK, 1986 apud Behringer; Boschetti, 2006).

A realidade nessa perspectiva é histórica e social e seu conhecimento atravessa um processo que compreende, primeiramente, a destruição da pseudoconcreticidade (ou seja, da apresentação do fenômeno aparente e fetichizado) e o conhecimento de sua autêntica objetividade; o segundo passo é o reconhecimento do caráter histórico do fenômeno; e em terceiro é o conhecimento do conteúdo objetivo e do significado do fenômeno, de sua função objetiva e de seu lugar histórico (KOSIK, 1986 apud Behringer; Boschetti, 2006).

Sendo, portanto, orientada por esse prisma, a pesquisa empírica promove também a desmistificação de saberes que se concretizaram no cotidiano e no senso comum da sociedade, qual seja, a impossibilidade de haver transformação social através da educação para presos.

Chauí (2001) revela algumas características próprias do senso comum de uma sociedade como: elas são individualizadoras, por serem qualitativas (são julgadas por nós) e heterogêneas (julgadas diferentes, por serem percebidas diferentes). Um exemplo dessa característica é quando se analisa superficialmente um presídio e os internos, acredita-se que não há seres humanos lá dentro, devido os crimes cometidos, e que os internos não podem retornar ao convívio por serem "animais".

Chauí (2001) ainda apresenta a característica de serem subjetivos e generalizadores, expressões de sentimentos de medo e de incompreensão, as certezas cotidianas e o senso comum de nossa sociedade cristalizam-se em preconceitos com os quais passa-se a interpretar toda a realidade. Buscando não incorrer nesse equívoco, essa pesquisa investiga a educação no presídio não apenas nos dados apresentados pelo sistema, mas na voz daqueles responsáveis pela condução do setor da educação, os educadores/professores.

Seguindo um roteiro de entrevista que visava abarcar os valores individuais do educador, bem como sua postura como professor, dentro e fora de sala de aula ${ }^{4}$, já que as entrevistas se deram em ambientes fora do presídio, foi possível ir do aparente ao real, a sua essência. A entrevista não sendo dentro do presídio permitia uma resposta menos

\footnotetext{
${ }^{4}$ Através da entrevista foi possível perceber a postura do professor, através não apenas da sua fala, mas de todo o seu apresentar, desde gestos a expressões faciais que permitiram identificar a fala não-verbal do educador.
} 
prejudicada pela lealdade ao local de trabalho. Não quer dizer também que algumas repostas não tenham sido polarizadas para o bem apresentar do sistema prisional, sendo os educadores parte do sistema.

De acordo com Chizzotti (1991, apud Cardoso, 2006), a entrevista é uma comunicação dirigida entre o pesquisador e o sujeito da pesquisa, privilegiando as informações sobre o objeto de estudo, que podem ser fornecidas pelos sujeitos. $\mathrm{Na}$ entrevista os princípios teóricos e metodológicos norteiam o diálogo podendo provocar reações decorrentes das vivências de cada sujeito.

Parafraseando Minayo (2000, apud Cardoso, 2006), a entrevista é um instrumento de produção de informações que contempla tanto a fidelidade do informante como o lugar social do pesquisado. Na fala é possível serem reveladas informações relevantes à pesquisa na medida em que apresenta as condições estruturais, os sistemas de valores, normas e símbolos daquele objeto estudado, como também revelar o caráter históricosocial das relações e das lutas sociais.

A entrevista com os educadores não seria suficiente, pois incorreria na redução do real a um lado, sem considerar o sujeito a quem a educação deve atingir, o educando. Dessa forma, entrevistas com educandos que já cumpriram sua pena se fez necessário para responder se a educação no presídio teve relevância para sua vida fora do sistema.

Para essas entrevistas, por se tratarem de sujeitos sociais que sofrem com o estigma da pena de reclusão, e não desejam refletir sobre essa época, a pesquisa teve de se valer de um método de entrevista menos tradicional: por telefone. Com isso os entrevistados se sentiam mais à vontade, por estarem incógnitos, sendo apenas ouvidos.

Apesar de não ser possível observar outros aspectos da entrevista, como os gestos e as demais expressões não-verbais, foi possível extrair informações mais próximas do verdadeiro. Os entrevistados sentiam-se descontraídos e menos infligidos pelo estigma de preso.

A seleção da amostra para a entrevista realizou-se por meio da indicação do Professor Doutor Mário Ângelo, da Universidade de Brasília, o qual selecionou educadores que haviam realizado curso de extensão na área de educação ministrados pelo mesmo, através da UnB.

A seleção dos educandos foi realizada por meio da ONG Catatau, que trabalha com egressos do sistema. Três educandos já haviam participado dessa ONG. Os educandos 4 e 5 foram indicados pela ONG Cerape $^{5}$.

\footnotetext{
${ }^{5}$ Catatau: Centro de Referencia, Intervenção e Pesquisa em Reinserção Social de Internos e Egressos do Sistema Prisional. Cerape: Centro de Recuperação e Apoio ao Preso e ao Egresso.
} 
Objetivava-se entrevistar 5 educadores e 5 educandos, contudo, por motivos que fogem à alçada pessoal da pesquisadora, foram realizadas 4 entrevistas com os educadores e 4 com os educadores. Um dos motivos foi a dificuldade de entrar em contato com os dois restantes.

Outro instrumento utilizado para desvelar o objeto pesquisado foi a coleta em bancos de dados oficiais, os quais serviram para embasar o corpo do trabalho e vislumbrar um universo mais diverso para a pesquisa. Os dados foram obtidos da InfoPen e estão no anexo $C$ da presente pesquisa.

Citando Mills (1975), "o objetivo da pesquisa empírica é solucionar desacordos e dúvidas sobre fatos, e assim tornar mais frutíferas as discussões, dando a todos os lados maior base substantiva". Esse é o objetivo da presente pesquisa. 


\section{CATEGORIAS TEÓRICAS}

\subsection{QUESTÃO SOCIAL}

A superlotação dos presídios brasileiros reflete um aumento exorbitante da violência urbana ${ }^{6}$, o que provoca uma reflexão sobre as causas da criminalidade. Buscase entender o que está por trás de um fenômeno que tanto é mascarado como algo particular, individualizado, mistificado em razão de sua apresentação personalizada na figura do "bandido".

Deve-se retornar à própria sociabilidade humana e seu fundamento na categoria trabalho, como também a historicidade da acumulação do capital que desemboca na forma contemporânea capitalista. Esse retorno histórico visa desvelar a essência do fenômeno e não incorrer no senso comum.

De acordo com lamamoto (2001), as expressões das desigualdades sociais têm início na produção dada coletivamente em contraposto à apropriação privada da atividade humana, o trabalho, é uma das formas de produção, através da apropriação dos meios de produção.

A questão social, como é apresentado o fenômeno, engendrado na fisiologia da própria acumulação do capital, é expressa pelas "disparidades econômicas, políticas e culturais das classes sociais" (IAMAMOTO, 2001). A tendência de naturalizar a questão social passa pelo crivo do capital para encobrir sua real faceta, sua gênese na acumulação capitalista.

De acordo com lamamoto (2001), essa naturalização é acompanhada pela sua transformação em expressões da violência dos pobres, em que se busca a resposta na segurança e na repressão oficial. Em Wacquant (2001) temos que o crescimento da violência criminal ${ }^{7}$ vem acompanhado pelo aumento da repressão policial, o que, contudo não surtiu efeito como solução.

Faz-se um retorno ao passado, quando a questão social era concebida como caso de polícia e incorre no mesmo erro quando se atribui as expressões da questão social

\footnotetext{
${ }^{6}$ No Sistema de Informações Penitenciárias - InfoPen, acessado em junho de 2007, é possível analisar a quantidade de presos/ internos relacionado ao número de habitantes da região. No Distrito Federal para uma população de 2.277.279 de habitantes, 7.267 estão internados em algum tipo de regime penitenciário (Ver anexo C).

${ }^{7} \mathrm{O}$ índice de homicídio no Rio de Janeiro, em São Paulo e Recife é de 40 para cada 100.000 habitantes, enquanto o índice nacional supera 20 para cada 100.000 habitantes (índice duas vezes o índice norte-americano do início dos anos 90 e 20 vezes o nível dos países da Europa ocidental) (WACQUANT, 2001).
} 
como responsabilidade individual. Perde-se a atenção na dimensão de totalidade dos processos sociais contraditórios que as criam e as transformam (IAMAMOTO, 2001).

Para a autora Yasbeck (2001), para se discutir a questão social no Brasil deve-se ressaltar a problemática do precário sistema de proteção social público, principalmente as políticas sociais. Ao dissertar sobre a questão social, ela recorre ao sistema falho de proteção aos mais carentes.

Para chegar na questão social, Yasbeck (2001) traz as conseqüências provocadas pelas redefinições do capitalismo, as quais conduziram crises em um processo de "mudança social regressiva". Agravaram substancialmente o já frágil tecido social. No Brasil, as conquistas sociais foram, de certa forma, conquistas enviesadas pelos poderosos, pela classe hegemônica, o que não contribuiu para o fortalecimento do tecido social.

Questão social como referência tem por parâmetro a questão da divisão da sociedade em classes, tendo por foco a luta pela apropriação de riqueza social. É uma questão estrutural que não se resolve numa "formação econômica social por natureza excludente".

Falar em questão social é qualificar a condição de pobreza, exclusão e subalternidade, ou seja, é preciso situar "ausência de protagonismo, de poder, expressando a dominação e a exploração" (YASBECK, 2001). Estas situações se configuram como indicadores de inserção social, de condição de classe, expressando as relações vigentes na sociedade.

Quanto à pobreza, a autora em questão apresenta como retrato da mão-de-obra barata e sobrante, descartada em face da expansão capitalista. A violência da pobreza faz parte do cenário brasileiro e expressam o quanto à sociedade pode tolerar a pobreza e banalizá-la. Não há mais espaço para um discurso da cidadania e dos direitos, este é ocupado pelo discurso humanitário da filantropia.

Diante do quadro negativo visualizado no Brasil, Yasbeck (2001) se questiona em como apoiar seu processo emancipatório, criar condições para seu protagonismo, compreender a dialética de "um fazer história à margem da realidade dominante e das idéias dominantes?".

Outra autora, Pereira (2001), que versa sobre essa temática critica como se vem utilizando o termo "questão social" que vem sendo imposto sem uma devida problematização e "sem enfrentamento à altura por parte de forças sociais estratégicas" (PEREIRA, 2001). Esse é um fato que contribui para a não compreensão do que o conceito abarca. 
Volta-se para a substância do capitalismo que é fundamentalmente a contradição entre capital e trabalho. Dentro dessa contradição, que é a pedra de toque do sistema capitalista desenvolvem-se as conseqüências que preenchem a sociedade hoje: os problemas sociais.

Faltam forças sociais com poder de pressão para incorporar na agenda pública os problemas sociais ingentes. Dessa forma, Pereira (2001) acredita que o problema jaz em uma questão social latente e não explícita.

A falta de visibilidade pública tem provocado uma insensibilidade coletiva frente ao aprofundamento da desigualdade social. Essas desigualdades têm inspirado políticas sociais minimalistas e até punitivas da pobreza, já que a pobreza tem sido responsabilizada pelos males da sociedade.

O grande problema está na relação entre estrutura e sujeito - confronto entre necessidade e atores sociais. De acordo com Pereira (2001) é preciso uma superestrutura favorável, ou seja, a presença de um Estado com capacidade de regular.

As teorias que hoje estão em voga são inquietantes, como a teoria de underclasses, como "fruto do inexorável processo de exclusão social e da "cultura da pobreza'”. Essas subclasses estariam dependentes da ajuda do Estado, conseqüência do Welfare $S_{t a t e}{ }^{8}$ e, por isso, justifica-se uma política contrária, uma política que valorize o workfare $^{9}$ ao contrário do welfare. Dessa forma, reforçam a ausência de um Estado regulador.

Daí Pereira (2001) propõe que as calamidades sociais que foram naturalizadas devem deixar essa condição. E, para tanto, apresenta para os profissionais que lidam diretamente com essas expressões, em especial, o Serviço Social o desafio de descobrir qual é sua contribuição e como participar na problematização.

Voltando ao panorama dos problemas sociais encontra-se, como expressão da questão social, a violência, que particularmente, vem assumindo um posto importante no discurso público, já que os resultados de sua demonstração são indicados em números de mortos e na intensidade do pânico nas metrópoles brasileiras. O Brasil contabiliza cerca de 30 homicídios para cada 100 mil habitantes ante a média mundial de 5 . 0 resultado anual de homicídios pode ser comparado ao número de vítimas de uma guerra

\footnotetext{
${ }^{8}$ Tipo de organização política e econômica que situa o Estado como agente da promoção social, cabendo-lhe garantir serviços públicos e proteção à população.

${ }^{9}$ Significa trabalho forçado, diferentemente do conceito de bem estar, já que a inserção consiste em forçar a aceitação de qualquer trabalho. Para aprofundar esse conceito ver: CARDOSO, Heloisa Helena Pacheco. Uma estranha ditadura. Rev. bras. Hist., São Paulo, v. 22, n. 43, 2002. Disponível em: $<$ http://www.scielo.br/scielo.php?script=sci_arttext\&pid=S0102-01882002000100014\&lng=en\&nrm=iso $>$. Acesso em: 30 Julho de 2007. Pré-publicação.
} 
civil, de acordo com pesquisa do Gabinete de Segurança Institucional (GSI), da Presidência da República, em parceria com a Universidade São Paulo (USP) e o Instituto Latino-Americano das Nações Unidas para a Prevenção do Delito e o Tratamento do Delinqüente (llanud), de 2001.

\subsection{VIOLÊNCIA}

Para refletir sobre a violência, apresento alguns autores que estudam essa categoria ou que instigam estudos acerca das causas e das conseqüências dessa expressão da questão social.

Dentre esses autores, Zaluar (2004) apresenta o debate contemporâneo que atem para a criminalidade e violência, e como esse debate tem imbricado na relação entre o campo político e o campo intelectual. Os cientistas sociais, tem demonstrado posturas diversas acerca desse tema. Alguns apresentam uma postura orgânica (aos moldes de Gramsci), ou específica (Foucault) ou uma postura universal.

Outros cientistas sociais ${ }^{10}$, ainda, se aprofundam no modelo marxista dicotômico de sociedade, modelo em que há duas classes sociais antagônicas. Um modelo de construção da sociedade em que se considera um paradigma - os pobres como protagonista dos crimes violentos.

Os estudos em que prevaleceu esse paradigma, de forma equivocada, geraram ambigüidades teóricas e modelos societários precipitados. Como o modelo da sociedade violenta em que a violência é legitimada na sociedade mais ampla. A violência passa a ser justificada como resposta "a altura" aos problemas sociais.

Retornando a atenção de seu trabalho para as pesquisas e estudos, Zaluar (2004), notou que "a questão institucional predominou de longe sobre uma perspectiva sociológica que focalizasse a sociedade na sua autonomia". Porém a autora ressalta “críticas às teorias sociológicas canônicas ainda 'enfocadas na causalidade' e envolvidas no próprio objeto". A preocupação dos estudiosos incidia na causa da violência e na resposta institucional para a mesma.

Para os estudiosos dessa temática, os autores como Marx e Foucault contribuem com sua visão de poder estatal e poder disciplinador - a polícia e a prisão. Duas versões

\footnotetext{
${ }^{10} \mathrm{Na}$ pesquisa de Zaluar (2004), a autora não se propõe apresentar os autores específicos que optam por determinados caminhos sociológicos de pesquisa, mas apresentar especificamente esses caminhos e que conseqüências geram na interpretação da realidade social em que vivemos.
} 
de um mesmo poder, o poder da classe dominante, pois o poder estatal está inclinado, dada a correlação de forças da classe dominante, e o poder disciplinador impõe o que essa classe estabelece: a disciplina para a produção.

Os autores que acreditam que a pobreza, a falta de educação e outros fatores sociais eram responsáveis pelo aumento da violência são considerados da "esquerda penal”. Já os que acreditam na eficiência da polícia em proteger, os que centram na questão institucional são considerados "de direita", e aqueles que fizeram da criminalidade objeto de atenção são os conservadores e empiristas.

Fajnzylber e Araújo Júnior (2001) realizaram pesquisa em que sugerem que o modelo econômico pode contribuir ao entendimento dos determinantes do crime no Brasil. Esses autores mesclaram abordagens distintas incidindo em uma perspectiva de análise mais profunda da realidade. A conclusão alcançada pela pesquisa foi que a relação entre desigualdade e crime, por exemplo,

"poder-se-ia argumentar que não é a desigualdade de renda per se a que afeta o crime mas sim outras características a ela associadas, como a capacidade de proteção privada ou a desigualdade na distribuição dos esforços de segurança pública, ou ainda a desigualdade na distribuição da educação ou mais geralmente da riqueza. Poder-se-ia pensar também que os efeitos sobre o crime decorrem de aspectos específicos da distribuição de renda, como a pobreza relativa de determinados segmentos econômicos ou a importância da classe média (o grau de polarização). Ou ainda (...) é possível que o relevante não seja o nível ou a estrutura da desigualdade mas sim o padrão de mobilidade social existente - tanto no sentido ascendente quanto descendente" (Fajnzylber e Araújo Júnior, 2001).

A preocupação excessiva, nos estudos e pesquisas, com limites reconhecíveis reificou as ditas subculturas criminais, dicotomizando o mundo, dos dominantes e o do marginal, o incluído e o excluído. Fazendo surgir a metafísica negativa, de Habermas, em que o mundo do desviante é uma alternativa ao mundo oficial e por isso é justificado (ZALUAR, 2004). Dessa forma a violência é uma estratégia de sobrevivência.

Centrada nessa preocupação atual, Zaluar (2004), notou os diversos estudos voltados ao "que é violência", promovendo a necessidade de se discutir sobre o conceito. Essa autora afirma que a violência passa a ser preocupação no campo da pesquisa na década de 1980, quando ganha destaque na mídia o aumento da criminalidade.

Nesse período, o problema da inflação atinge o nível social interferindo na sociabilidade, refletindo na própria violência. A riqueza no processo ilegal é apropriada por outros agentes que não tem a legitimidade social do empreendedor. 
De acordo com Zaluar (2004), surge um fascínio pelo crime nessa época, pois compensava. Diante dos graves problemas que a sociedade vivenciava, o jovem pobre se revoltava frente à situação e frente ao Estado e buscava no crime o enriquecimento rápido.

Buscando entender o conceito -"Violência vem do latim violentia, que remete a vis (força, vigor, emprego de força física, os recursos do corpo para exercer a sua força vital). A força torna-se violência quando ultrapassa um limite ou perturba acordos tácitos e regras que ordenam relações, adquirindo carga negativa ou maléfica". (ZALUAR, 2004)

$O$ discurso recai sobre o porquê da violência desvelando a miséria crescente, o desemprego, a falta de serviços públicos eficientes, principalmente saúde, educação e ausência de políticas sociais. Isso tudo era entendido como "violência perpetrada pelo Estado contra a população necessitada" (ZALUAR, 2004), o que gerava a violência contra o poder ilegítimo do Estado.

A autora considera violência estrutural como o sinônimo de desigualdade, exploração, dominação, exclusão, segregação, e outros males associados à pobreza. Mais uma vez a questão da pobreza é enfocada no mesmo quadro que a violência, assumindo similaridades em seu combate.

Em seu estudo, Zaluar (2004), ressalta outro aspecto da violência, a que se apresenta muda e que exclui e domina por meio da linguagem. Entra no debate a questão da educação, que falha ao não imprimir um espaço adequado para o cidadão se expressar, ou seja, a violência se espalha pela falta de recursos objetivos para o ser humano reagir.

A falha da educação repercute como falhas na estrutura da cultura brasileira que se expressa pela ausência de concepção de cidadania, uma ausência da noção de direitos. Gerando, assim, uma falta de apoio da população a política de direitos humanos. Isso resultaria na resposta da sociedade frente à violência incitando mais violência.

"A ação ilegal da polícia seria decorrência da construção imaginária desse bode expiatório da crise social e política brasileira, que negava os direitos civis e humanos aos bandidos pobres". (ZALUAR, 2004).

Os estudos sobre a violência explicada - justificada - pela lógica da acumulação capitalista, pelas determinações socioeconômicas, e os estudos que tentam vincular a pobreza com a criminalidade, freqüentemente apresentam fragilidades na argumentação. "Afirmar a associação entre pobreza e criminalidade, e pobreza e violência, leva a um claro viés que reforça a discriminação contra os pobres, tanto nas instituições 
encarregadas de reprimir o comportamento considerado criminosos, quanto no imaginário da população em geral" (Paixão, 1983 apud Zaluar, 2004, p.257).

Buscando resolver o problema transfere-se o milagre para as políticas públicas de prevenção e repressão. Supõe-se que vencidos os problemas que pioram a violência como baixa eficiência do sistema educacional e de saúde, venceria o aumento da criminalidade. É claro que no Brasil, isso é apenas suposição, já que estamos longe de vencer esses problemas.

Apresenta-se essa missão ao intelectual compromissado com a democratização da sociedade, já que o conhecimento sociológico revela quais são as necessidade sociais a serem atendidas pelas políticas públicas.

A resposta do Estado na década de 1980, contudo, recai nas políticas públicas, as quais não satisfaziam, pois eram ineficazes e ineficientes. Acrescentava-se a essas características a abrangência minimizada dessas políticas, não abarcando a todos que dela precisavam. Outra grave conseqüência das políticas públicas falhas durante a década foi o número pouco favorável de crianças e jovens pobres na escola, mesmo com o crescimento da rede escolar no país (ZALUAR, 2004).

Diante desse quadro, a autora não apresenta dúvidas sobre a correlação entre baixa escolaridade e baixa renda. Essa correlação desemboca em outra referente à pobreza e a criminalidade. Pressupõe um fortalecimento na política educacional para reduzir, ou minimizar a questão da violência, mas o debate é pouco mais complexo, porque a situação social no país é mais complexa e envolve mais agentes sociais e mais estruturas sociais.

A escola em si, ou seja, a instituição não pode ser responsabilizada pelos resultados da violência. Não é a instituição, mas seus agentes, os sujeitos sociais imbuídos da tarefa de educar que perecem com a responsabilidade. São os agentes sociais que orientam o caminho a ser percorrido.

Os resultados da educação falha geraram o generalizado desrespeito às regras da convivência social, provocando agravos na teia social brasileira. Incluí-se aqui a visão redentora do intelectual compromissado, que se insere em um quadro desolador, o qual utiliza teorias (e as glorifica), quando não são mais trabalhadas por cientistas sociais estrangeiros.

Essas teorias revogadas são influentes para com os intelectuais brasileiros. Zaluar (2004) apresenta a teoria que vislumbra os seres humanos em objetos e seu comportamento em fatalidade ou determinação, baseados no posicionamento positivista, e são influentes até hoje no Brasil. 
Outras teorias buscam a relação entre a determinação social, e o positivismo que a autora apresenta como:

“... teoria das classes perigosas, formulada por Chevalier (1978) para descrever e entender a vida social, política e literária de Paris no século XIX. Segundo essa teoria haveria uma associação clara e indiscutível entre a classe operária e, formação na cidade, suas condições miseráveis de vida, e a exploração de violência e criminalidade, que por sua vez despertaria grande interesse folhetinesco na classe operária e um forte temor, aliado ao desejo de segurança, nas classes média e burguesa de Paris no Século XIX" (ZALUAR, 2004).

A criminalidade violenta passa a ser entendida pela questão nacional e ética sem desconsiderar a questão social com o desmantelamento dos bairros operários e ao enfraquecimento do movimento operário.

"O princípio explicador de sua conduta não seria a pobreza (ou a cultura da pobreza), mas a exclusão, termo que se refere a diversos processos simultâneos, entre os quais o desemprego, o afastamento da escola, a estigmatização pelo uso de drogas, o enfraquecimento dos movimentos sociais (novos e velhos), assim como a diluição dos laços sociais nos bairros operários" (ZALUAR, 2004).

Outro processo que provoca exclusão decorre da violência policial e da prevenção judicial contra os jovens que se envolvem nas atividades criminosas, que segrega os mesmos em bons e maus, os que já se enquadraram no sistema e os que ainda não se enquadraram. Torna-se uma mácula para a vida desses jovens, que são identificados por ela.

O conceito de exclusão retoma alguns aspectos da underclass - conhecida e utilizada na França, não sendo utilizados os pressupostos teóricos e as implicações desse conceito de inspiração estadunidense. Guarda proximidades teóricas desenvolvidas na América Latina a respeito do mercado informal e da marginalidade, vinculando, sobretudo o econômico ao social.

"Exclusão vincula o econômico ao político e ao social, mas tem por referências, além da cidadania e da inserção na sociedade nacional, as fronteiras entre os grupos e a lógica classificatória (não explicitadas), referencias nem sempre claras para os que usam o conceito de forma abusiva entre nós" (ZALUAR, 2004). 


\subsection{EXCLUSÃO/ INCLUSÃO}

Para tratar da exclusão é preciso entender a que está se referindo o termo, ou seja, se há exclusão significa que o contrário, a inclusão é real. Para Castel (1998), os incluídos são aqueles que estão "integrados”, os grupos ou indivíduos inscritos na relação de produção da riqueza e do reconhecimento social.

Pereira (1998) identifica a inclusão social como importante função da política de assistência social, que busca contribuir para a universalização ou extensão da cidadania. Parto por estender essa função para a política de educação, também uma política social abertamente voltada para a construção do ser crítico e cidadão.

Os problemas da exclusão associados às formas de pobreza têm agravado as tensões e comportamentos disruptivos como a violência e o uso indevido de drogas, de acordo com a análise de Pereira (1998).

Para Pereira (1998), a exclusão social é um fenômeno multidimensional que não se limita à insuficiência de renda ou ausência de renda, mas se expressa na combinação de várias desvantagens que impedem o excluído de pertencer à sociedade e de ser nela reconhecido como cidadão, sujeito de direitos.

Para a autora supracitada, a inclusão seria o primeiro passo para o processo de resgate dos excluídos. Contudo essa inclusão não se dá apenas pelo acesso do indivíduo a serviços que lhe são negados. O sujeito excluído possui vulnerabilidades que não cessam após o simples participar institucional em que se considera incluído.

Autores como Demo (1998), discordam que a problemática da exclusão seja um fenômeno novo e argumenta que a impressão é falsa, o que na verdade se tem de novo é a fase do capitalismo. Dentro do debate já apresentado da questão social, incorre-se nesse mesmo equívoco de se ter na aparência atual algo de certo e verdadeiro.

Abordando esse conceito tão polêmico os autores Stoer, Magalhães e Rodrigues (2004), trabalham com o binômio inclusão/exclusão e o enquadram em referência de sua implicação no corpo, no trabalho e na educação.

$\mathrm{Na}$ categoria trabalho os autores lembram a economia vigente que abriu espaço para a globalização, onde a "inserção (de poucos) se dá no sistema produtivo", ou seja, dentro dessa categoria o conceito de exclusão se identifica com a história pós-moderna de produção capitalista, em que o incluído é aquele que participa do sistema. 
Neste mundo "mercantilizado" existem duas tendências, que esses autores trazem: a luta pelo reconhecimento das diferenças ${ }^{11}$, como afirmação de cidadania; e a "conclamação da regulação como instrumento de garantia da justiça social e não mais a emancipação, para garantir-se o mínimo de proteção pessoal contra a investida excludente do capital globalizado".

Percebe-se no debate desses vários autores a importância da cidadania para a superação da exclusão, ou seja, a luta pela defesa dos direitos, a afirmação de sua abrangência para todos configura em um passo decisivo na intenção da inclusão social.

Existe, porém, uma "tensão dinâmica entre o instituído e o instituinte", provando que nada está engessado. Esses lugares em que o par simbiótico produz impacto são, também, os lugares em que se chega a conclusões, soluções. Porém, o que se tem presenciado no estágio atual do capitalismo é um recrudescimento das conquistas sociais angariadas através de muita luta, e um reaparecimento da sociedade de risco.

"Sociedade de risco", de Bek, implica o

"retorno da incerteza à sociedade: cada vez mais os conflitos sociais são tratados não como problemas de ordem (que, por definição, são orientados para a clareza e para a capacidade de decisão), mas como problemas de risco. Estes problemas de risco são caracterizados por terem soluções ambíguas (...). Face a uma crescente falta de clareza (...), a crença na viabilidade técnica da sociedade desaparece quase por necessidade" (Stoer, Magalhães e Rodrigues, 2004, p.24).

Gera-se nessa sociedade de risco a idéia da impossibilidade de se chegar a uma conclusão e, portanto, a esperança de mudança, de transformação social é perdida na onda de incertezas sociais.

A exclusão possui uma natureza multidimensional devido a suas múltiplas causas e múltiplas conseqüências. Exemplo disso se expressa nas duas concepções que o conceito abarca: a primeira está relacionada à literatura identificada com a sociologia do desvio e a sociologia dos indivíduos e grupos marginalizados (os clássicos da "Escola de Chicago"). Castel (1998) traz clara sua teoria do marginal que não é excluído, mas pode vir a ser, já que não participa das regras e normas sociais.

A segunda concepção se relaciona com a época atual, o "pós-fordismo", onde a exclusão tem a ver com o resultado do desemprego de longo prazo, desemprego de jovens, formas de emprego precário, entre outras. Estaria ligada ao mundo do trabalho.

\footnotetext{
${ }^{11}$ Há uma luta pelo estabelecimento do diferente, e não pela igualdade "homogenizadora". As lutas são de reconhecimento dos homossexuais, dos negros, dos índios, entre outras, e não mais a luta pelo respeito humano em geral.
} 
Essa segunda concepção traz a questão da exclusão como norma, quando se assume como ponto de partida a idéia de que o "mercado é que define a inclusão, substituindo-se dessa forma as funções do Estado-nação e o seu paradigma de proteção social, sobretudo sob a bandeira do Estado Providência ou Etat Providence" (STOER; MAGALHÃES; RODRIGUES, 2004).

De acordo com esses autores aquilo que as pessoas possuíam em comum (território, linguagem, religião, grupo étnico, história) era o fator determinante para a definição dos incluídos no espaço nacional e, dessa forma, aptos para o exercício da cidadania.

Tanto na concepção medieval quanto na moderna, da ontologia social a inclusão é definida pelo seu oposto a exclusão e mesmo a erradicação da diferença. Os que ficam às margens da sociedade não são passíveis de serem considerados legítimos participantes na sociedade, não são considerados cidadãos.

Citando Cardoso (2006),

"O Brasil, nos últimos anos, apresentou um aumento considerável em sua população carcerária, indicando um aumento da violência no contexto da sociedade, cujas causas são os fatores sócio-históricos e políticoeconômicos ocorridos na sociedade brasileira. A criminalidade, que ora se desenvolve na sociedade brasileira, é parte integrante de uma população excluída das condições mínimas de sobrevivência, em que as necessidades essenciais à vida estão relegadas aos mais baixos indicadores sociais. Essa população excluída irá continuar a fazer parte de um outro grupo caótico de exclusão, referindo-se aqui à população carcerária" (p.51).

\subsection{RECLUSÃO/PRIVAÇÃO DE LIBERDADE}

\section{História das prisões}

$\mathrm{Na}$ Antigüidade o encarceramento não era como sanção penal, mas como local de custódia e tortura, frente à espera da execução da pena. Normalmente essa execução se dava com métodos punitivos concentrados na dor e no sofrimento humano.

Foucault (1977) discursa a respeito do funcionamento objetivo da punição nos presídios e nas formas antigas de encarceramento. Todas essas formas envolvem a disciplina, como forma de manter o controle. Esse controle se sustenta através do espaço (nas distribuições dos indivíduos), dos horários, e em qualquer instância do ser que o possibilite se descontrolar, se expressar livremente, seja não fazendo nada, seja 
escolhendo o que fazer. Entra aqui a noção de tempo ocioso, que é severamente repreendido pelo sistema. Se na antiguidade clássica, o tempo livre servia para a reflexão, para o trabalho da mente livre, no encarceramento, o ócio significa a não remissão.

$\mathrm{Na}$ Idade Média, o sistema prisional desenvolveu-se em consonância com o desenvolvimento econômico, cultural e social das sociedades ocidentais (Cardoso, 2006). É importante ressaltar que com o agravo social sofrido pelas classes subalternas, devido o desenvolvimento econômico promovido pela industrialização emergente, a criminalidade aumentou e propiciou que as punições fossem mais severas.

Essa correlação demonstra a interligação entre o desenvolvimento econômico, o qual excluiu muitos dos trabalhadores rurais, e as péssimas condições de vida, que ocasionaram um aumento da criminalidade.

No século XIX, iniciou-se o desenvolvimento das penas de reclusão de liberdade, com a construção e criação de prisões, conhecidas como "Casas de Correção". Vale ressaltar mais uma vez, a ligação entre o desenvolvimento econômico com o processo de desenvolvimento das prisões, tendo em vista que as transformações econômicas no final do século XVII transformaram as "Casas Correção" em unidades de produção. Os internos são, também, mão-de-obra barata.

No século XX, evolui o debate sobre a elaboração teórica e prática que resultou no surgimento da "Ciência das Prisões". Surgiu, aí, a pena privativa de liberdade.

Instituições totais como as prisões, segundo Goffman (1974, apud Vidal 2006), seriam "nas sociedades lugares de coerção destinados a modificar a personalidade das pessoas nelas internadas, bem como suas atitudes e comportamentos, a fim de que esses sujeitos sociais respondam por meio de adaptações manifestas pela aceitação das regras, interiorização das normas e dos valores" (p.34).

Com a luta aberta pelos direitos humanos que eclodiu com a Declaração Universal dos Direitos do Homem, em 1948, elaborada pelas Nações Unidas, contribuiu para o avanço da Ciência Penitenciária, em termos de observância dos direitos dos apenados e em relação da execução da pena no ambiente prisional.

Constitui base para essa luta a questão da dignidade humana e da cidadania. Essas são obscurecidas frente o olhar disciplinador e regulador do sistema prisional. Os internos são sujeitos de direitos, mas que nem sempre podem fazer valer seus direitos.

Em sua pesquisa Vidal (2006), afirma que as instituições prisionais são povoadas, em sua maioria, por sujeitos que, inicialmente, não apresentam condições de inclusão no mercado de trabalho. "Essas pessoas têm perfil similar em toda sociedade ocidental, são em sua maioria migrantes, negros ou afrodescendentes, sem alfabetização e 
profissionalização, cujos delitos, em sua maioria, são contra a ordem e a propriedade privada" (p.35).

\section{O direito e a cidadania}

No contexto de direitos humanos a execução da pena passou a ser inscrita no princípio da reabilitação social. O Estado passa a ter a responsabilidade de prevenir o delito e o dever de evitar a reincidência, orientando e preparando o apenado para o retorno à sociedade.

Foi promulgada a Lei n. ${ }^{\circ} 3.274$, em 1957, que dispõe sobre as "Normas Gerais do Regime Penitenciário". Essa promulgação coincidiu com a divulgação das Regras Mínimas para Tratamento dos Presos de 1955, da ONU. A abordagem com o apenado difere, sendo mais digna, já que ele passa a ser visto como sujeito de direito, um cidadão, em condição especial (direitos civis cerceados), mas um cidadão.

De acordo com Cardoso (2006), no Brasil sempre houve uma falta grave com relação à preparação ao retorno, para a reinserção do apenado na sociedade. As atenções sempre se intensificaram para a prevenção do delito e controle da criminalidade. Há um déficit no setor de políticas sociais voltadas a garantir esse retorno.

A Lei de Execução Penal (LEP), Lei 7.210, foi promulgada em 1984, na época do processo de redemocratização do país, sendo garantida através dela, os direitos dos apenados. A partir daí, se insere o debate sobre a cidadania, com ênfase na garantia dos direitos dos apenados, sobre a humanização da pena.

Para T.H. Marshall (1967), os direitos civis, políticos e sociais, em conjunto constituem a cidadania. A conquista desses direitos pode ser historicamente situada. A cidadania é conquista dos direitos universais e é também a luta pela defesa desses direitos, podendo ser reconhecida através das condições históricas, econômicas, culturais e sociais.

Cardoso (2006) cita Platão no que concerne à cidadania em que a "formação do cidadão se dá por meio da educação e do sentimento de pertença ao Estado-nação". Esse conceito relaciona-se à lealdade do sujeito ao Estado, sendo distinto o bom e o mau cidadão de acordo com sua utilidade e produção à sociedade.

O conceito de cidadania incorporou a condição econômica e social, tendo como princípios básicos a igualdade e a liberdade. O conceito foi moldado na fase de industrialização, sendo influenciado pelos novos valores morais, éticos e jurídicos advindos da classe burguesa. Marx, ao estudar essa fase, acreditava que uma revolução 
se fazia necessária para a emancipação humana, em que o homem não seria subjugado pela propriedade. O elemento responsável pela emancipação seria a cidadania.

Citando Coutinho (1997, apud Cardoso, 2006): “A cidadania não é dada aos indivíduos de uma vez, para sempre, não é algo que vem de cima para baixo, mas é o resultado de luta permanente travada quase sempre a partir de baixo das classes subalternas, implicando um processo histórico de longa duração" (p.49).

Segundo Carvalho (2001, apud Cardoso, 2006), “a justiça social é a idéia central em que se baseia a concepção de cidadania na modernidade, pois a ausência de uma população educada tem sido sempre um dos principais obstáculos à efetivação da cidadania civil e política, principalmente no Brasil” (p.50).

Ainda Cardoso (2006), "cidadania é conquista e participação consciente; não é dádiva do Estado e, sim resultante da correlação de forças entre o Estado e a sociedade, sendo a tendência de universalização que a caracteriza na modernidade"(Covre, 1998 e Coutinho, 1997, apud Cardoso, 2006, p.52).

Esse debate acerca dos direitos dos apenados também se insere na ciência penitenciária, que se faz com o estudo do direito, e possui um caráter interdisciplinar da sociologia.

Busca-se estudar com isso o problema da efetividade legislativa - do fosso entre a Lei e a realidade social. De acordo com Madeira (2004), na busca pelas construções legislativas como solução eficiente para os problemas sociais, nesse fazer ciência penitenciária faz com que legisladores e intelectuais se deparem com os atores a quem o direito penal se destina, como os internos.

Não há ciência penitenciária que não esteja engajada na luta por melhorias do sistema e da vida das pessoas que "perdem seus rostos, sua identidade, cidadania, para tornarem-se uma massa, uma multidão a quem a população em geral retruca em ter de sustentar: os' vagabundos', 'os bandidos'“. (MADEIRA, 2004, p.43)

A questão do direito e das políticas sociais torna-se mais preocupante para aquele universo mais invisível do que o dos presos: os que saem das prisões. Esses ficam às margens da sociedade por carregarem o espectro do presídio e acabam excluídos do convívio social.

Madeira (2004), ainda apresenta o problema da falta de precisão das estatísticas, onde "os censos acabam por distorcer a realidade prisional, fazendo com que a proposição de políticas públicas penais também destoe de sua realidade e não seja, por fim, eficaz". 
Quanto à preocupação com a população carcerária, esta se concentra em sua (re)inserção social. De acordo com Passetti (2004), o diferente não é admitido, e deve ser ressocializado. Esse autor afirma que "estão em jogo os dispositivos suplementares de solução que envolve o uso da terapia (observadas as pertinentes anotações de Foucault acerca dos riscos de se substituir a prisão pela terapêutica), a educação (em sentido amplo de sociabilidade diferenciando-se de instrução cujo limite é a laborterapia) e a compensação (o que não implica em transformar o agressor em escravo da vítima)" (p.18).

Passetti (2004) cita Godwin, o qual não via "a prisão como lugar de educativa reflexão crítica moral do indivíduo frente a um suposto delito justamente julgado, de ressocialização ou de futura integração social; ela era apenas um lugar de aprimoramento de delinqüentes e de acelerada corrupção" (p.19).

Esses autores apresentam suas idéias acerca do objetivo da prisão e do encarceramento, e de suas falhas quanto a esses objetivos. Wacquant (2001) apresenta a contradição disseminada em um Estado neoliberal, no que concerne à penalidade aos infratores, qual seja um Estado policial e penitenciário mais rígido e radical, em contrapartida a um Estado econômico e social.

O papel da prisão, hoje, volta-se para a ressocialização e (re)inserção social, mas para alcançar esse horizonte faz uso de alguns instrumentos como a educação.

\subsection{EDUCAÇÃO}

\section{Assistência educação}

A LEP normatiza juridicamente a defesa dos direitos e dos deveres do apenado, prevendo concessões de benefícios e punições durante a execução da pena. Esses benefícios são: a progressão de regime prisional, a concessão de trabalho interno e externo, saídas especiais, atendimento à necessidade de saúde, educacionais e de profissionalização, e estão previstas também punições caso não sejam cumpridas as regras estabelecidas e regimentadas.

Citando Cardoso (2006), "para ocorrer a inclusão social dos apenados é necessário o seu resgate social. Este só será possível por meio da efetivação de políticas sociais de inserção, desenvolvendo e ampliando para políticas sociais de integração, com 
finalidade de desenvolver junto ao recém-incluído a revitalização de seus vínculos social" (p.18). Dentre essas políticas de inserção, privilegia-se a educação.

A pesquisa da autora supracitada buscou averiguar se a operacionalização dos artigos da LEP que tratam sobre os direitos cidadãos carece de mecanismos que os viabilizem como direitos e, devido a isso, acabam tornando-se mecanismo de benemerência e favorecimento.

A fim de averiguar esses objetivos a autora percebeu que a "ressocialização" do apenado continua a ser realizada por meio do tratamento penal, pois o delito continua a ser entendido como uma doença social, visto como fruto de um desviante social. Contudo a prática da ressocialização "demonstra a falência de teorias e de sistemas punitivos e, nesse sentido, abre caminho para a busca de novas alternativas, pois a pena privativa de liberdade é banalizada em nome da defesa social e em detrimento da condição de cidadania do apenado" (CARDOSO, 2006, p. 56).

Aos apenados está prevista uma garantia de seus direitos dentro da LEP, que se caracteriza como "assistência", onde prevê as atenções básicas que devem ser prestadas com vistas ao "tratamento" do apenado. Dentre essas "assistências" encontram-se, a assistência material, à saúde, jurídica, à educação, social, psicológica, ao trabalho e à profissionalização. Esse conjunto visa à recuperação da conduta desviante.

Citando Cardoso (2006),

"A LEP, ao focalizar as ações no delito se esquece que o apenado é um sujeito sócio-histórico e necessita de ações de políticas sociais. Entretanto, as ações desenvolvidas no interior do Sistema Penitenciário primam pela segurança e pelo confinamento, sendo um indicador da ocorrência da conduta desviante, pois seu foco continua a ser o delito e não a pessoa que o cometeu".

O Sistema Penitenciário no Brasil, de acordo com Cardoso (2006), é o retrato fiel de uma sociedade desigual, marcada pela ausência de políticas sociais para o enfrentamento das situações específicas da questão social, bem como pela falta de elaboração de uma política pública voltada para a cidadania de milhares de homens e mulheres presos.

Para Faleiros (1991, apud Cardoso, 2006), as políticas sociais surgem de um embate entre as forças em ação, forças políticas, econômicas e sociais das classes sociais no sistema capitalista. Resultam da interação entre o Estado e a sociedade, emergindo a relação capital e trabalho. 
Com essa perspectiva que se pensa em políticas sociais de inclusão para os apenados, as assistências. Busca-se conter o agravamento das desigualdades sociais. No capítulo II e III da LEP estão previstas as assistências ao recluso e ao egresso do Sistema Penitenciário com a intenção de prepará-lo para o retorno ao convívio social. Dentre elas encontra-se a assistência à educação.

A educação não tem o mesmo privilégio que a assistência ao trabalho, tendo em vista que o trabalho garante a remissão da pena com celeridade, já a educação não possui essa vantagem, o que a torna menos vantajosa.

Citando Cardoso (2006),

\begin{abstract}
"a inclusão dos apenados nas atividades está pautada na condição meritória, presente nos critérios da disciplina, pois só é classificado para o estudo o apenado que não está respondendo Procedimento Administrativo Disciplinar ou não constam faltas graves em seu prontuário jurídico e, caso ocorra alguma situação disciplinar durante o seu processo pedagógico, ele poderá ser punido com o desligamento do Núcleo Educativo" (p. 134).
\end{abstract}

A autora apresenta que mesmo que as punições estejam previstas na LEP, não significa que a direção não tenha autonomia para punir com a suspensão do benefício com a intenção de manter a disciplina. O que a autora apresenta é a falta de mecanismos operacionalizadores da Lei que impeçam a transformação dos direitos, como da educação, em favorecimento do sistema.

Ribeiro (2006) demonstra a preocupação em apresentar a relação entre exclusão e educação social, viabilizado pela tentativa de atravessar a aparência do real, buscando inserir o debate na essência. Essa autora trabalha com a hipótese de

"que existe uma disputa entre projetos sociais e educacionais contraditórios, resultando, daí, estratégias de combate à exclusão e promotoras de inclusão, encarnadas em concepções e práticas de educação social, como respostas às demandas de políticas sociais públicas provenientes das populações de crianças e jovens em situação de vulnerabilidade" (p.1).

\title{
Educação ampla
}

A questão da educação no presídio, como na escola, ou em qualquer instituição irá perpassar pelo viés da questão de classe. As instituições, principalmente totais como a prisão, transmitem os valores da classe dominante e não situa o aspecto da cidadania e 
emancipação humana, pois seria contraditório transmitir as ferramentas para uma luta de classes mais igual. Por isso a educação vislumbrada para a transformação social é a educação ampla, social, a educação para a vida.

A autora Ribeiro (2006), procura apresentar o problema conceitual que encerra no debate de exclusão e inclusão. O conceito se apresenta na realidade empírica, porém não se encerra na superfície, e esse é um problema em que se aborda o conceito de forma simplista. Ele vai mais longe, devendo recorrer aos processos históricos, abarcando os problemas que fazem parte das relações sociais no modo de produção capitalista.

Essa autora busca compreender a exclusão social, pois esta se vincula indissociavelmente ao conceito de educação social, sendo lhe atribuída a função de responder por esse problema. Ela apresenta a experiência de educação social no Uruguai que surgiu a partir de questões e necessidades dos educandos na qualidade de sujeitos sociais. "Uma análise dessa experiência, ainda que limitada pela exigüidade de informações, ressalta sua potencialidade como campo de experimentação de estratégia de formação de novos sujeitos sociais de direitos" (p.4).

No Brasil, a educação social está voltada, em princípio, para a formação do cidadão. A Pedagogia social de rua trabalha com uma realidade que corresponde com conteúdos e métodos opostos à escola formal, articulada a um compromisso político com os educandos.

Citando Ribeiro (2006),

\footnotetext{
"os educadores uruguaios afirmam que a escola se identifica com o ensino e que a educação social vai além do ensino, para abarcar o conjunto das atividades que os educandos desenvolvem no cotidiano, considerando-se os aspectos físicos, psíquicos e intelectuais. Tem-se aí uma retomada da perspectiva grega de educação integral para o cidadão" (p. 8).
}

Contudo não estamos lidando aqui com a educação de rua, mas a educação no presídio. O contexto é diverso, mas o conteúdo não difere tanto, está embasado na realidade do educando e visa constituir os sujeitos em cidadãos.

Essa visão da educação como meio de transformação social é cuidadosamente argumentado por alguns autores. Demo (1941) começa em seu trabalho com uma crítica em relação ao papel desenvolvimentista realizado pela educação, em que havia a crença de que a educação além de transformar as pessoas também servia como "via certa de saída do subdesenvolvimento". Os problemas eram todos relacionados à falta de 
educação, "até mesmo o problema do menor abandonado, da prostituta pobre, da violência urbana era produto de família sem educação".

A intenção do autor se justifica na adequação da educação no quadro da política social. Caracteriza política social como um "esforço planejado de reduzir as desigualdades sociais", sem, contudo, deixar de entendê-la como algo mais complexo, sendo possuidora de um caráter contraditório e dialético.

Já como política social, a educação procuraria minimizar as mazelas do capitalismo, onde há uma radical desigualdade de classes sociais. Colocada necessária para a ascensão social, a educação veio a ser uma preocupação de ordem política por acentuar a variável sócio-econômica da ocupação e da renda, pois contribuiria para a preparação da mão-de-obra.

O autor busca apresentar a impotência da educação frente à diminuição da desigualdade social para, assim, apresentar soluções para essa impotência. Contextualizando a atuação da educação em um "horizonte subdesenvolvido, de industrialização deficitária e dependente, com um quadro rural em degradação inevitável e com uma urbanização inchada, a educação tende a ser um remendo social, solidificando a ilusão do pobre, segundo a qual quem estuda sobe na vida" (DEMO, 1941). Dessa forma, a educação contribui para encobrir uma realidade opressora com um manto de possibilidade de ascensão através do próprio sistema que rebaixa.

O teor negativo em relação a educação faz coro à sua tendência de mantenedora da situação de dominação, ela "é sobretudo socialização, ou seja, outorga de normas, valores, sanções, que reproduzem a estrutura de privilégios e de distâncias sociais. É serva do poder. É indução à obediência" (DEMO, 1941).

Irrelevante seu papel de ascensão social principalmente por ser a educação seletiva, "favorece mais ao favorecido", a explicação dada é seu caráter elitizado construído historicamente. A resposta a esse problema se encontraria em uma orientação da política educacional para as áreas rurais e da periferia urbana, onde a pobreza é mais concentrada.

Citando Demo (1941), "O ensino formal tem-se demonstrado aí particularmente inadequado, e resta a impressão incômoda de que teríamos que reinventar quase tudo. (...) Os conteúdos curriculares estão muito distantes da estratégia de sobrevivência dos pobres, que se adapta mal a noções urbanas e consumistas da serialidade, da aprovação, das férias, etc". Resposta encontrada no entendimento das estratégias de sobrevivência do pobre ser aí um componente favorável. 
Um papel importante da educação se encontra em ser instrumento para a participação popular, dentro do regime democrático. Claro está que serviria também a não participação já que pela educação são socializadas as normas a serem seguidas e não questionadas. Porém, realizando esse movimento contrário a educação permitiria às massa populares participarem politicamente, sendo portanto, um "elemento importante na criação das regras democráticas de jogo e que são condição essencial para o projeto de redução da pobreza" (IDEM, IBIDEM).

Não caindo aqui na ilusão de acreditar que somente o componente político seria suficiente para diminuir as desigualdades sociais. A educação política é "simplesmente aquela que colabora na formação da democracia, onde preponderam regras igualitárias de jogo, buscando cercear privilégios econômicos" (IDEM, IBIDEM).

A pesquisa é apresentada pelo autor como um exemplo da dificuldade da educação reduzir a pobreza. As pesquisas seguem um caminho contraditório em que o pesquisador ao pesquisar sobre a pobreza, a verdade o faz para méritos particulares e acadêmicos e menos pela apreciação de um horizonte possível de redução de desigualdades e de pobreza. As pesquisas estão se encerrando em conhecimentos já adquiridos, ou de busca por conhecimentos sem função realista, ou por pesquisas "pretensamente descompromissadas" (IDEM, IBIDEM).

O autor sugere que as pesquisas educacionais sejam: comprometidas com a política do planejamento da educação; que elucidem a relação entre educação e pobreza, educação e participação, educação e política social; que avaliem a política educacional constantemente, buscando soluções e superações; busquem a inclusão no quadro das hipóteses; direcionem os resultados de forma a serem operacionalizadas na intervenção da realidade; critiquem as tendências negativas ao fenômeno pedagógico e promovam a autocrítica sempre; e que busquem ser mais corajosas do que busquem a objetividade, mais contato com a realidade do que a formalização, mais propostas do que tabelas.

Demo (1941) se mostra crítico diante da educação por ser ela identitária de duas possíveis tendências: uma a de ser ilusória, pois propaga a idéia de ser alavanca social, quando na verdade serve ao poder e ao poder é mantenedora.

A outra tendência é a de ser uma política social e como tal, pode minimizar os problemas sociais, ou seve para combater a desigualdades sociais procurando na redistribuição oferecer possibilidade de enfrentamento. Possivelmente a ultima tendência se sirva das duas alternativas. É interessante como a educação como enfrentamento da pobreza e da desigualdade encontre em sua promoção da democracia seu maior instrumento para a mudança da realidade. 
Outro autor discursa sobre a educação com um tom mais otimista para com a mesma. Freire (1970) apresenta em seu livro as observações feitas durante os cinco anos de exílio, especificamente em observações durante a execução das atividades educativas.

Nas primeiras palavras do autor há um claro posicionamento diante do que o livro aborda, ou seja, o que ele apresenta são idéias e ideais que exigem do leitor uma abertura. Ao desvendar os que têm medo da liberdade, pois ela oferece possibilidade de mudança, ou seja, de transformação do status quo, Freire desafia os que engessam a realidade. Estes que transformam a realidade em uma de duas opções, quais sejam: o fatalismo, daquele reacionário, que acredita na sina, no futuro não ideal; e o direitista que espera uma manutenção do hoje, ou melhor, uma volta ao ontem.

Para estes dois a leitura não abriria possibilidades, já que a tendência a qual estão orientados a seguir é a de negar a realidade como possibilidade. Somente o revolucionário, que não se prende a fragmentar a realidade para dar conta da mesma, é capaz de compreender o processo de construção do futuro.

A justificativa que o autor apresenta refere-se à problematização do homem, enquanto busca conhecer-se a si mesmo. Ao questionar-se sobre quem é, o homem toma consciência de sua incompletude, de sua capacidade de tornar-se a ser. Porém reconhece a desumanização como realidade histórica. Constatação esta, que os inscreve no movimento de busca pela humanização. Esta busca é possível, pois a "desumanização, mesmo que um fato concreto na história, não é, porém, destino dado, mas resultado de uma 'ordem' injusta que gera a violência dos opressores e esta, o ser menos".

Esta busca, esta luta pela mudança só poderá ser realizada pelos oprimidos, pois o opressor busca apenas amenizar o sofrimento dos oprimidos, imprimindo a estes uma falsa generosidade, a qual tem necessidade de manter. Dessa forma a capacidade de libertação se encontra nos oprimidos e nos que com eles "realmente se solidarizem".

Com a luta pela libertação do oprimido, há uma contradição inerente. Os oprimidos conscientes de sua situação de oprimidos entendem que sua transformação deva surpreender-se na comparação com os opressores. Um grande problema já que para os oprimidos ser mais seja tornar-se opressor.

Isto decorre da situação de "imersão" vivido pelo oprimido, imersão na realidade opressora. Dessa imersão que os oprimidos ao buscarem a mudança buscam a situação de opressão, de serem como os opressores, pois vêem a si mesmos como menos aquilo que deve ser, e vêem no opressor como o ser mais, aquilo que almejam. 
O medo da liberdade advém dessa imersão na realidade opressora. A liberdade significaria duas opções concretas desafiadoras. A primeira desafia o oprimido, o qual vive sob "prescrições", ou seja, seu comportamento é mediado pela imposição do opressor sobre a realidade, a conquistar a autonomia.

O oprimido ao viver sobre a sombra do opressor tem nessa sombra a orientação a seguir, e essa orientação desapareceria a partir da tomada de responsabilidade, a qual configura a liberdade. A segunda seria a contradição, imersos na realidade opressora, ao se libertarem transformar-se-iam em opressores.

Citando Freire (1970),

\begin{abstract}
"Sofrem uma dualidade que se instala na 'interioridade' do seu ser. Descobrem que, não sendo livres, não chegam a ser autenticamente. Querem ser, mas temem ser. São eles e ao mesmo tempo o outro introjetado neles, como consciência opressora. Sua luta se trava entre serem eles mesmos ou serem duplos. Entre expulsarem ou não ao opressor de 'dentro' de si. Entre se desalienarem ou se manterem alienados. Entre seguirem prescrições ou terem opções. Entre serem espectadores ou atores. Entre atuarem ou terem a ilusão de que atuam, na atuação dos opressores. Entre dizerem a palavra ou não terem voz, castrados no seu poder de criar e recriar, no seu poder de transformar o mundo". (pg 8)
\end{abstract}

A concretização do "homem novo" se dá através desse "parto" que se realiza na superação da contradição opressores-oprimidos. Esse "parto" é possível na medida em que o oprimido compreenda que o mundo desenhado pelos opressores se caracteriza como um limite à sua completude, a sua liberdade. Compreenda que a realidade não está engessada e que pode ser transformada e principalmente não se limite a compreender, mas que se engaje na luta por libertar-se, que se entregue à práxis libertadora.

Essa superação da contradição é uma superação objetiva da situação opressora e "exige a inserção dos oprimidos na realidade opressora, com que, objetivando-a, simultaneamente atuam sobre ela". Dialeticamente participa a subjetividade em uma permanente integração com a objetividade. É nesse discurso de objetividade e subjetividade que o autor reconhece o perigo de cair em duas situações: o objetivismo, que nega a subjetividade, e o subjetivismo, que cria uma realidade imaginária, uma falsa realidade.

Essas duas situações possíveis de ocorrer na análise da realidade são constituintes de um problema de analisar ingenuamente. Como há a imersão do oprimido na realidade opressora, essa imersão funciona como "domesticadora" da realidade, por 
isso é necessária a realização de uma ação e reflexão para a transformação. Não incorrendo nos erros ingênuos descritos anteriormente.

$\mathrm{O}$ autor identifica dois momentos distintos da pedagogia do oprimido. O primeiro momento é o do comprometimento com a práxis, com a libertação, a partir do desvelamento da situação de opressão pelo oprimido; o segundo momento, depois da realidade opressora ter sido transformada, a pedagogia deixa de ser do oprimido e passa a ser a pedagogia dos homens em um processo constante de libertação.

A questão do opressor frente ao movimento de mudança da situação de opressão é ainda mais perturbadora, pois acostumado com essa situação em que ele tudo pode devido sua posição dominante, sequer pensar em outra forma de relação é inadmissível.

Dessa forma o opressor não pode participar do mesmo ideal de transformação, de libertação, e o vê como algo subversivo e perigoso. Já está tão naturalizada a situação de opressão, da posição de um ser mais por ter mais, e de outros não serem e nem poderem ser ou ter, que seria um ataque ao direito de possuidor que os opressores têm a mudança da situação.

Em face de tudo isso está a preocupação com aqueles que passam de exploradores para o pólo dos explorados, pois estão carregados por um "medo do povo". Apesar de acreditarem estar lutando pelo povo não se permitem lutar com o povo, de entregarem a voz ao povo.

Revestem-se de um discurso a favor do povo quando na verdade não crêem no povo. Daí que a passagem de um pólo para o outro "deva ter significado profundo de renascer. Os que passam têm de assumir uma forma nova de estar sendo; já, não podem atuar como atuavam; já não podem permanecer como estavam sendo".

$\mathrm{Na}$ dependência emocional que os oprimidos tem em relação ao opressor suscita as manifestações de destruição da vida. Seja a violência "horizontal" com seus iguais, seja a violência com a própria vida. Em prol de uma mudança real dessas condições é que a luta de transformação engajada na práxis libertadora deve indubitavelmente incluir o "diálogo crítico e libertador".

Não sendo confundido com a comunicação verticalizada ou com a manipulação para a transformação de massa de manobra o diálogo se faz com o oprimido. É com "a sua inserção lúcida na realidade, na situação histórica, que a levou (a pessoa oprimida) à crítica desta mesma situação e ao ímpeto de transformá-la” (IDEM, IBIDEM).

Por isso o diálogo deve ser feito com a pessoa e não "depositado" na pessoa como se esta não fosse sujeito e sim objeto. E dessa forma constrói-se uma prática 
pedagógica em que o método não é instrumento do educador, pois o educando já tem consciência e não se permitiria ser manipulado pelo educador.

A educação bancária é oposta à educação pretendida, a educação libertadora. A primeira propõe-se a servir como mantenedora da situação de opressão quando nega o conhecimento construído em comunhão entre educador e educando. Neste caso o educador é o depositário do conhecimento e das prescrições do mundo opressor.

Cabe aos educandos serem receptores alienados desse depósito perpetuando sua situação de oprimidos e a situação de opressão. O autor ressalta a impossibilidade de mudar essa realidade dentro da estrutura que reflete a estrutura do poder, caberia ao educador responsável pelo diálogo dialogar sobre a negação do próprio diálogo.

A educação libertadora intenciona a "emersão" da consciência do oprimido e assim a inserção crítica deste na realidade. O ponto principal para se alcançar essa intenção está no desvelamento do mundo opressor pelo educador e educando em um movimento de construção do conhecimento conjuntamente e dialeticamente.

Conhecendo-se o homem um ser histórico, ou seja, inacabado, em um devir ser constante, "a educação se re-faz constantemente na práxis. Para ser tem que estar sendo". A educação libertadora problematiza a situação do homem, propõe a situação como problema e não como o "destino" prevê, tornando assim, possível a mudança na realidade. "Dessa forma, aprofundando a tomada de consciência da situação, os homens se 'apropriam' dela como realidade histórica, por isto mesmo, capaz de ser transformada por eles" (IDEM, IBIDEM, p. 32).

O autor constrói a possibilidade de enfrentamento da situação de opressão através da educação. Educação dos oprimidos frente à situação de opressão, conscientizando-se de seu papel transformador da realidade. Ainda mais importante, o autor revela a educação sistemática como incapaz de ser libertadora, pois serve à estrutura dominante, serve ao capital. Os oprimidos são personagens vitais e valiosos na mudança de sua situação. Eles são os sujeitos e não objetos da educação.

Em outro trabalho Freire (1984), combate a concepção ingênua da pedagogia que se crê motor ou alavanca da transformação social e política. Combate também o oposto, o pessimismo sociológico que acredita que a educação reproduz mecanicamente a sociedade.

Esse autor analisa as possibilidades e os limites da educação, em que nasce um pensamento pedagógico que leva o educador e todo profissional a se engajar social e politicamente, a perceber as possibilidades da ação social e cultural na luta pela transformação das estruturas opressivas da sociedade classista. 
O autor supracitado incita o compromisso social afirmando que "a primeira condição para que um ser possa assumir um ato comprometido está em ser capaz de agir e refletir" (FREIRE, 1984, p. 16).

O ser que está imerso no mundo, incapaz de distanciar-se para admirar é ahistórico, pois está fora do tempo ou "sob" o tempo, não podendo se comprometer. O compromisso é práxis - tem o componente da ação e da reflexão sobre a realidade -, implicando um conhecimento da realidade. Se vemos a realidade estática, imutável, não é possível um compromisso autêntico.

"É transformando a totalidade que se transformam as partes e não o contrário. No primeiro caso, sua ação, que estaria baseada numa visão ingênua, meramente "focalista" da realidade, não poderia constituir um compromisso" (FREIRE, 1984).

Há uma ameaça para o compromisso verdadeiro: ameaça que se concretiza na autenticidade do compromisso - a alienação cultural. Citando Freire (1984): "A alienação estimula o formalismo, que funciona como espécie de cinto de segurança. Daí o homem alienado, inseguro e frustrado, ficar mais na forma que no conteúdo; ver as coisas mais na superfície que em seu interior" (p.25).

Núcleo fundamental onde se sustenta o processo de educação é o inacabamento ou inconclusão do homem e o fato deste saber-se inacabado e por isso se educar. "Não há educação sem amor" (IDEM, IBIDEM).

O homem é capaz de refletir sobre sua realidade e assim levantar hipóteses sobre desafios postos na e pela realidade e procurara soluções. Nas palavras de Freire (1984):

\footnotetext{
"A educação não é um processo de adaptação do indivíduo à sociedade. O homem deve transformar a realidade para ser mais. (...) Uma educação que pretendesse adaptar o homem estaria matando suas possibilidades de ação (...). A educação deve estimular a opção e afirmar o homem como homem. Adaptar é acomodar, não transformar" (p. 32).
}

Nesse espaço de investigação sobre o campo da educação - "campo de recontextualização pedagógica" (STOER, 2004, p.14) - os professores são como agentes de re-contextualização. Stoer (2004) cita Basil Bernstein, em que o professor tem por função "selecionar, simplificar e transferir o conhecimento que eles reproduziram" (p.15). Incorrem assim no inevitável tipo de "educação monocultural com efeitos predominantemente reprodutivos (o que Paulo Freire denomina 'educação bancária')" (IDEM, IBIDEM, p.16).

Citando Stoer (2004), "se o professor procurar uma grande variedade de materiais educativos, tentando re-interpretar, re-situar e re-focalizar o manual com o objetivo de se 
comunicar com os estudantes provenientes de contextos sociais e culturais diversificados, existe maior possibilidade de o professor escapar - pelo menos parcialmente - aos efeitos reprodutivos do sistema educativo; e ainda produzir ativamente conhecimento que pode ser de dois tipos. O primeiro é o conhecimento socioantropológico produzido a partir da observação cuidadosa do grupo de estudantes (...). O segundo tipo de conhecimento resulta da fertilização cruzada de conhecimentos baseados no currículo e na pedagogia em interação com o conhecimento socioantropológico obtido a partir das diferentes formas de observação" (Stoer, 2004:16). 


\section{ANÁLISE DO OBJETO}

A análise do objeto seguirá o formato da apresentação do trabalho, ou seja, as categorias teóricas apresentadas anteriormente servirão para fundamentar a análise do discurso dos entrevistados. Dessa forma, será possível compreender as falas dos entrevistados em vários aspectos.

\section{QUESTÃO SOCIAL}

Através das entrevistas com os sujeitos que já cumpriram a pena de privação de liberdade foi possível analisar seu perfil, confirmando dados oficiais do Departamento Penitenciário Nacional ${ }^{12}$ com relação ao fator da cor/raça: do total de 4 entrevistados, 3 afirmaram serem da cor preta ou parda. Isso apóia um dos dados alarmantes que sugerem que a população negra (de cor preta ou parda) sobressai à população branca presa.

De acordo com os dados do Ministério da Justiça, 4.967 (quatro mil e novecentos e sessenta e sete) pessoas ${ }^{13}$ são consideradas negras ou pardas, aproximadamente $68 \%$ do total da população carcerária. Confirma-se mais um fato relevante para entendermos um aspecto importante das configurações das expressões da questão social no Brasil.

A população negra tem sido apontada como aquela parcela da população que não tem as mesmas oportunidades de acesso que a população branca, e que por isso estão destituídas de um poder de enfrentamento frente às necessidades sociais. Isso tende a acirrar as diferenças sociais, e situa a questão racial como expressão de dominação e exploração de uma classe social sobre outra.

Do dado supracitado depreende-se que a população negra carcerária é duplamente excluída, primeiro excluídos de políticas públicas básicas como educação, saúde, moradia, entre outras; e excluídos pela estigmatização de terem sido ou serem presos.

Ainda sobre o perfil dos educandos, os entrevistados estão caracterizados em: 2 deles no intervalo de 25 a 30 anos; 1 entre 31 e 36 anos; e 1 entre 43 e 48 anos. A porcentagem de presos na faixa etária entre 18 e 34 anos, no Distrito Federal, é de

\footnotetext{
12 Os dados oficiais citados e referenciados foram fornecidos pelo Sistema Integrado de Informação Penitenciária - InfoPen, no Anexo C.

${ }^{13}$ A população estudada refere-se ao sexo masculino. Todas as estatísticas analisadas foram baseadas nesse recorte, em decorrência de todos os entrevistados serem do sexo masculino.
} 
aproximadamente $78,1 \%$. A questão de serem jovens e estarem presos dificulta uma possível (re)inserção, se não possuírem dentro do presídio uma formação que os capacite para o retorno à sociedade.

O fato de estudarem é importante para os internos, pois como o Pedro ${ }^{14}$ disse "as pessoas que procuram ir à escola são vistas com bons olhos pelos agentes, (...) você nota respeito por aqueles que optam por estudar ou trabalhar".

\section{VIOLÊNCIA}

Analisando os dados oficiais sobre a qualificação dos crimes tentados ou consumados, observa-se que o número de crimes que constituem roubo, furto ou latrocínio chega a 7.281 . Um total de $49,44 \%$ dos crimes no Distrito Federal se enquadra na tentativa de "enriquecer fácil". Pode-se inferir que a busca da classe desfavorecida de mudar de vida tenha sido por meios ilícitos, reforçando a idéia mistificadora de relacionar pobreza com violência.

\section{EXCLUSÃO/ INCLUSÃO}

Dentro dessa categoria de análise é permitido vislumbrar várias facetas de uma mesma questão. Os excluídos, de acordo com PEREIRA (1998), não podem ser reduzidos apenas àqueles que apresentam insuficiência de renda, mas da combinação de vários outros fatores.

A partir da fala do Marcos, pode-se perceber que a educação não é vista como a "salvação" para o problema de estarem presos, recuperando-os. Tampouco servirá para (re)inseri-los na sociedade, uma vez que nunca estiveram inseridos. Ele afirma que a classe baixa, ou os pobres, não possuem acesso a uma educação de qualidade, ou a um sistema de saúde pública eficiente. Daí conclui que esses mecanismos de convivência humana podem apontar quem realmente está incluído ou não, reforçando a condição de não incluídos.

A partir da fala dos quatro educandos, contudo, percebe-se que a educação é importante para fazê-los sentirem-se integrados à sociedade, enquanto participantes de

\footnotetext{
${ }^{14}$ Os educandos entrevistados receberam nomes fictícios para preservar seu anonimato, pois não desejam serem conhecidos como ex- detentos. O educando 1 recebeu o nome de João, o educando 2 de Pedro, o educando 3, Marcos, e o educando 4 o nome de Mateus. Quanto aos educadores foi adotado o uso de letras para indicá-los.
} 
políticas como educacional, de saúde, habitacional, entre outras políticas públicas. Mesmo não possuindo a oportunidade de estudarem quando jovens livres, enquanto cumpriam a pena perceberam a importância da educação.

O Marcos afirmou ter feito curso superior para "mostrar para a sociedade que mudou". Essa mudança esclarecida a todos é importante como ritual de passagem de interno presidiário para cidadão honesto. Ele confessou ter sido perseguido dentro da universidade por ser ex-detento, mas que perseverou quando percebeu que educação é um direito. O Pedro afirmou que a educação serviu para "alavancar, abriu minha mente, (...) através da educação eu consegui participar".

Os depoimentos sobre a educação como meio de inserção na sociedade faz perceber que mesmo que os educandos não acreditem que a educação no presídio tenha sido eficaz em seu papel de (re)inseri-los, fora do presídio ela realizou esse papel. Prova disso que dos quatro entrevistados, dois possuem nível superior completo (Pedro é formado em Pedagogia e Marcos é formado em Filosofia), um possui superior incompleto (Mateus fez parte do curso de Psicologia) e um possui o ensino médio completo (João).

\section{RECLUSÃO/ PRIVAÇÃO DE LIBERDADE}

A questão da prisão envolve, também, outros sujeitos que puderam responder de forma aberta e sem receio o que de fato acontece, os educadores. A característica de vigiar, punir e tratar ainda está muito forte dentro dos presídios do Distrito Federal. Todos os quatro educadores entrevistados informaram que, apesar de se esforçarem para dentro de sala serem apenas professores e alunos, o fato de serem vigiados por um policial (ou agente de segurança), o qual permanece durante toda a aula, observando através de uma parede cobogol ${ }^{15}$, faz lembrar a todos que ali é um presídio.

Além de vigiarem de perto, os internos antes de entrarem em sala de aula são revistados, bem como quando saem da sala. $O$ educador $B$ dá aula de artes e afirmou ser quase impossível que seus alunos possam fazer alguma coisa, ou aprender muito se nem podem trabalhar com materiais cortantes ou suspeitos.

Outros educadores reclamaram que seus alunos não podem sequer levar um lápis para fazerem as tarefas extraclasse. Torna-se uma tarefa difícil ensinar com essa atmosfera de trabalho, quanto mais aprender.

\footnotetext{
${ }^{15}$ Parede Cobogol é de tijolos com furos em formato de círculos de mais de $5 \mathrm{~cm}$ de diâmetro, facilitando o guarda que fica do outro lado da mesma fiscalizar os alunos e professores.
} 
Outro aspecto relevante da prisão dentro do setor educacional é a relatividade com que a educação é tratada em cada unidade. $\mathrm{O}$ educador $\mathrm{C}$ ao responder sobre as práticas democráticas no presídio, afirmou que ela depende da unidade, já que na unidade de segurança máxima e de segurança média não é permitido aos internos opinarem. Nem é permitido aos educadores opinarem para mudar essa situação, já que na prisão o mais importante é a segurança.

O educador A revelou que no presídio o núcleo de educação é o mais fraco. Isso significa que na correlação de forças, os educadores possuem menos força, já que não há aliados significantes para fortalecerem sua luta.

O horário das aulas foi um ponto argumentado por todos os educadores entrevistados. As aulas são ministradas três vezes por semana, o que não é suficiente para dar conta de todo o conteúdo. As aulas, também não são contínuas, durante a semana, dois dias são reservados para as visitas familiares. Portanto, as aulas devem ser interrompidas, retornando somente após o final de semana.

O João acredita que esse sistema de aula, com constantes interrupções, desestimula, uma vez que quando retornam devem reaprender o que já foi ensinado. Os educadores também sentem que é um desafio para os educandos, bem como é um atraso para a educação que já cumpre um calendário mais corrido.

O controle dos horários na prisão é uma técnica de disciplina para o controle dos internos. Dessa forma a educação deve se sujeitar ao segundo plano para se prevalecer a segurança e o controle sobre os mesmos.

Quanto às escolhas pela educação ou trabalho, de acordo com os educandos, essa não é exatamente uma escolha. O João não freqüentou a escola no presídio, pois no período em que esteve sobre privação de liberdade, ele se alistou para ser "classificado". Esse era o termo para aqueles internos que não gostariam de ficar no ócio.

Esse educando foi "sorteado" para o trabalho. Em suas palavras "no uni-duni-tê me jogaram para o trabalho. Na realidade eu queria era estudar. (...) O grande lance é você não ficar parado, no ócio, maquinando, porque você sabe cabeça vazia...".

O ócio é abominado pelos agentes do sistema, e na fala dos educandos percebese que a questão do respeito está ligada ao fato de estarem realizando alguma atividade. O fato de estarem trabalhando ou estudando não significa nada em termos de importância humana, para a formação cidadã ou dignidade. A importância de uma atividade é que se pode controlar os internos mais de perto.

Mesmo que, em sala de aula, os professores afirmem que os alunos/internos são tratados com respeito, são vistos como sujeitos de direitos, os próprios educandos 
reconhecem que são educandos em uma situação peculiar, internos de um regime de reclusão.

\section{CIDADANIA}

No roteiro de entrevistas foram feitas perguntas tanto para os educadores quanto para os educandos a respeito da cidadania e dos direitos de cidadão. Foi interessante perceber o que é entendido por cidadania pelos dois grupos.

Os quatro educadores relacionaram ser cidadão no Brasil com ter direitos e deveres garantidos em Lei. Elencaram os principais direitos que foram: direito à educação, saúde, moradia, de ir e vir, entre outros.

Já os quatro educandos responderam que cidadania são direitos não cumpridos e deveres, os quais devem ser cumpridos. O Mateus respondeu que os deveres "devem ser cumpridos com rigor".

Percebe-se que a visão sobre ser cidadão pela ótica de quem já cumpriu a pena de privação de liberdade está voltada para a questão dos deveres. De certa forma ser cidadão é para eles cumprir mais seus deveres do que ter direitos assegurados. O João acredita que ser cidadão é "ter deveres e obrigações e coisas a cumprir". Sequer ele mencionou ter direitos.

O próprio contrato social é baseado na relação de troca, entre receber seus direitos e cumprir seus deveres. Para internos, ou que já cumpriram pena, o fato de viverem sem a troca justa, conhecerem apenas um lado do contrato, percebem que aquele que o quebra é punido por isso.

Vale ressaltar que todos informaram o direito à educação como direito do cidadão. O direito ao trabalho ou ao emprego também foi muito mencionado, pelos dois grupos. Infere-se daí que os direitos básicos não são desconhecidos, só não estão sendo buscados.

Aos educadores foi perguntado sobre o objetivo da educação no presídio estar voltada para a formação cidadã, o que revelou que apenas o educador $A$, que ensina Artes, acredita que sim. Os demais educadores responderam que a educação no presídio deveria estar voltada para a cidadania e que chegam a buscar esse objetivo. Contudo, a questão já mencionada da estrutura e organização da educação não favorece alcançar essa meta. 
Apesar de vários fatores não serem contributivos para a formação cidadã no presídio, o educador $B$ revelou que em muitos casos, o interno só vem a conhecer alguns de seus direitos dentro do presídio, estimulados por meio da educação, por meio dos profissionais da educação.

O educador D acredita que o aluno/interno nunca deixou de ser cidadão e que o objetivo da educação seria a (re)inserção social. Os demais educadores informaram que as atividades desenvolvidas a fim da formação cidadã constituem-se da própria educação formal, de projetos artísticos, de atividades cívicas, de trabalhos voltados à questão do meio ambiente e voltados à questão do homem.

Quanto à questão da democracia, as respostas variaram bastante. Os educadores responderam que democracia tem a ver com direitos e deveres. O educador $C$ afirmou que seria "casar direitos e deveres".

O educador A respondeu ser, também, participar e reconhecer o outro. O educador B acredita que seja ter direito a opinar e se expressar. Em relação aos educandos, o João respondeu que "não tem significado nenhum viver numa sociedade democrática. Eu vivo a vida. No meu modo de vida não significa nada".

Para o Pedro, "você só é cidadão quando vive em uma sociedade democrática, porque demo vem de povo e cracia é poder. Povo no poder. Só existe democracia se os cidadãos começam a agir. Não consigo desvincular uma coisa da outra". O Marcos respondeu que é "ter acesso à educação, saúde, a direitos que dão dignidade à pessoa humana".

Já o Mateus respondeu ser "liberdade de escolha, de expressão. No Brasil é bom, não temos tanta repressão. Mas a desigualdade priva da democracia, e a ignorância".

\section{EDUCAÇÃO}

De acordo com os dados do Ministério da Justiça, 97\% dos internos possuem um grau de instrução entre ensino fundamental e médio. Esses dados não oferecem motivos para vitória, tendo em vista que o grau de instrução indica apenas a série que o interno está cursando ou já cursou. Isso significa apenas a instrução recebida.

A educação vai além da instrução, além de aprendizagem. Para o Marcos a educação ampla, não reduzida à socialização das regras e preceitos da sociedade é "um instrumento facilitador". Atualmente, no presídio, a educação está longe de ser eficaz no que se propõe, a (re)inserção social. Para esse educando há que se trabalhar outros 
aspectos primeiramente, como distribuição de renda justa, para depois mudar alguma coisa.

Para o Pedro, apesar de sua experiência em educação não ter sido favorável, já que em sua época, eram os detentos que davam as aulas, ele conhece pessoas que hoje freqüentam as aulas no "galpão", como é conhecido o Centro de Progressão Penitenciária, com professores concursados, são pessoas diferentes. Para ele "a pessoa que é educada, que é trabalhada, a educação envolve muita coisa, ocorre uma mudança. Um marginal passa a ser consciente dessa condição (ele dá o exemplo do homem na caverna de Platão, que descobre que o mundo não é de sombras), têm novos horizontes".

Para os educadores a educação e o trabalho são os instrumentos de mudança daquele sujeito social cumprindo pena. Para o educador $A$, através da educação, o sujeito começa a se conscientizar de seus atos e passa a refletir sobre sua vida, só assim ele seria capaz de mudar.

Mateus respondeu que a educação dentro do presídio seria eficaz se mudasse sua abordagem militarizada. De acordo com ele, quando esteve cumprindo pena, por discordar de certos atos da direção e ter promovido um abaixo assinado, recebeu como retaliação o confisco de livros e o transferiram de unidade. Para ele, a educação não deveria ser tratada como concessão de bem, deveria ser ampla, para todos; um quesito de socialização.

O Marcos acredita que para ser eficaz a educação tem que ser para a vida. Ele citou Paulo Freire que dizia que a educação facilita a se tornar crítico e aprender a tomar suas decisões criticamente. Essa educação para a vida se constituiria de uma educação formal mais uma educação para repensar e criticar a sociedade e a si mesmo.

Quanto a Paulo Freire e seu método de aprendizagem, vai-se além dos recursos e instrumentos de que se faz valer para promover a educação. Atravessa questões sobre o relacionamento educador e educando, entre outras.

Todos os educadores entrevistados conhecem o método ou filosofia de Paulo Freire. Porém, essa forma de entender a educação não participa formalmente do plano de curso dos professores. Eles utilizam informalmente, sem sistematizar, quando abarcam aspectos da vida dos alunos para mover e motivar as aulas.

Quando questionados se a educação participa para a emancipação dos sujeitos sociais todos os educadores responderam que sim. Através da cultura, dos direitos e da conscientização é que se promove essa emancipação.

Já para os educandos foi perguntado o que significa ser livre. Essa pergunta se referia a um aspecto filosófico da educação que se insere na questão da conscientização. 
Só se pode conscientizar-se quando se está livre da opressão. Eles responderam que "liberdade é a coisa mais linda, que é tudo".

Pedro respondeu que não existe ausência de liberdade, que mesmo preso você é livre para respirar. "Liberdade é estar consciente de tudo que está a sua volta, é interagir, é interação".

Essas respostas permitem vislumbrar o valor atribuído à liberdade enquanto potencialidade de "emersão". Esse termo utilizado por Paulo Freire refere-se à capacidade do sujeito de enxergar-se do lado de fora, de criticar-se e posicionar-se crítico diante do mundo. Essa capacidade é relevante para o processo de emancipação humana.

A partir da análise do discurso percebe-se que a educação no presídio não tem sido capaz de (re)inserir os internos, mas que pelo compromisso dos profissionais da educação e pela vontade dos que já cumpriram pena é possível que essa realidade mude. A emancipação humana, por meio da educação é possível, basta ser assumida com responsabilidade. E quanto a isso percebe-se que nos presídios do Distrito Federal, já se têm iniciado esse processo. 


\section{CONSIDERAÇÕES FINAIS}

A conclusão atingida através da pesquisa é otimista e vislumbra potencialidades felizes para o futuro do processo de (re)inserção social dos apenados. Em vista da realidade passada e da que vivemos hoje, o caminho para a efetivação dos direitos de cidadão está sendo realizado. De forma morosa, mas realizado.

Os princípios humanos e cidadãos conquistados, após muita luta, apesar de não serem completamente proporcionados a todos, em sentido universal e igualitário, encontram-se em via de ampliação. Essa ampliação tem sido proporcionada por meio da educação.

A educação não participa apenas na instrução e formação profissional de uma pessoa. Quando proposta a ser mais ampla e completa, revestida de valores mais humanos favorece a conscientização do sujeito, ensejando uma tomada crítica de participação da vida social. Só assim, poderia se concretizar a cidadania para todos.

Dentro desse contexto de autonomia, a educação participa do campo otimista para a mudança do sistema prisional, principalmente favorecendo uma mudança por parte dos sujeitos a que a ação do presídio se direciona: os internos. Uma mudança direcionada e promovida pelos próprios internos constituiria o movimento sempre constante do instituinte transformando o instituído. Esse movimento, hoje, é promovido pelos agentes penitenciários e pelos demais agentes do sistema de justiça e segurança, não estando perto de uma mudança justa.

Apesar de não ser vislumbrado nessa pesquisa o início desse movimento novo, não se perde de vista sua possibilidade, haja vista que o papel da educação no presídio tem angariado respeito e compromisso, tanto pelos educadores, como pelos educandos.

Mesmo sendo otimista a conclusão dessa pesquisa não se pretende ingênua acreditar que a educação hoje esteja realizando todo seu potencial de instrumento de transformação social. Percebeu-se através da fala de ex-internos que a disposição para estudar não foi algo estimulado pelo sistema, mas almejado pela necessidade de se fazer ouvir, de ser incluído.

O sistema prisional em Brasília, mesmo progredindo na área da educação, com as aulas sendo ministradas por profissionais da área e com um setor organizado, padece de força política dentro e fora do presídio. As conquistas sejam de recursos ou de atividades a serem realizadas, são através de muita luta e muito diálogo. As aulas são vigiadas por agentes penitenciários e depende da posição favorável desses agentes para o bom 
funcionamento. Isso significa que se o agente encarregado não acredita que o interno deva receber o benefício da educação, ele não será favorável a qualquer mudança para a melhora do núcleo.

Isso expõe o longo caminho para concretizar a cidadania, para estabelecer direitos fundamentais. A educação no presídio não é benesse, tampouco é instrumento de vigia e guarda, ela é direito, e serve ao cidadão, para sua conquista de uma liberdade que vai além da liberdade física, mas a liberdade da alma.

Conclui-se que a educação quando promovida para além da socialização de regras sociais, quando promove a conscientização, é objetivamente instrumento de (re)inserção social. E esta educação tem sido buscada pelos educadores dos presídios do D.F. , quando eles afirmam que buscam trabalhar para além de conteúdos programáticos estipulados pela Secretaria de Educação. Trabalham temas que envolvem a vida dos internos, assuntos que importam para o crescimento humano de cada um, como os direitos humanos e a sua efetivação, ou a questão do meio ambiente.

A presente pesquisa não se pretende estar acabada, mas servir de alavanca para mais pesquisas na área, mais efervescência nesse campo tão pouco estudado e tão pouco valorizado, mas que se apresenta como instrumento, como meio para a realização de uma sociedade mais justa e humana. Finalizo citando Paulo Freire (1984): "não há transição que não implique um ponto de partida, um processo e um ponto de chegada. Todo amanhã se cria num ontem, através de um hoje. De modo que o nosso futuro baseia-se no passado e se corporifica no presente. Temos de saber o que fomos e o que somos para saber o que seremos". 


\section{REFERÊNCIAS BIBLIOGRÁFICAS}

BEHRING, Elaine Rossetti; BOSCHETTI, Ivanete. Política social: fundamentos e história. São Paulo: Cortez, 2006.

CASTEL, Robert. Os marginais na história. In Ser Social 3: Exclusão e situação de risco. Revista do programa de pós-graduação em política social do Departamento de Serviço Social da Universidade de Brasília, julho - dezembro de 1998.

CARDOSO, Maria Cristina Vidal. A cidadania no contexto da Lei de Execução Penal: o (des)caminho da inclusão social do apenado no Sistema Penitenciário do Distrito Federal. Dissertação de Mestrado em Política Social, Brasília: Universidade de Brasília Departamento de Serviço Social, 2006.

CHAUÍ, Marilena. Convite à filosofia. São Paulo: Ática, 2001.

DEMO, Pedro. Política social e política educacional. Educação, cultura e política social. Porto Alegre - RS: Editora Feplam, s/d.

Exclusão social: novas categorias para realidades velhas. In Ser Social 3: Exclusão e situação de risco. Revista do programa de pós-graduação em política social do Departamento de Serviço Social da Universidade de Brasília, julho - dezembro de 1998

Pesquisa e informação qualitativa. São Paulo: Papirus, 2001.

FAJNZYLBER, Pablo; JÚNIOR, Ary de Araújo. Violência e Criminalidade. Texto para Discussão $n^{\circ}$ 167. Universidade Federal de Minas Gerais, Faculdade de Ciências Econômicas, Centro de Desenvolvimento e Planejamento Regional, Outubro de 2001. Disponível em: <http://www.cedeplar.ufmg.br/pesquisas/td/TD\%20167.pdf>. Acesso em: 30 de juIho de 2007.

FOUCALT, Michel. Vigiar e punir - nascimento da prisão. Ediora Vozes, Petrópolis, 1977.

FRAZÃO, Virginia Jardim. Do ócio da prisão à linguagem dialética da educação. Dissertação de Mestrado. Faculdade de Educação, Universidade de Brasília, 1995. 
FREIRE, Paulo. Educação e mudança. Rio de Janeiro: $8^{a}$ edição, Paz e Terra, 1984.

FREIRE, Paulo. Pedagogia do Oprimido. 17ª ed. Rio de Janeiro: Paz e Terra, 1970.

IAMAMOTO, M. Vilela. A questão social no capitalismo. In Revista Temporalis. Associação Brasileira de Ensino e Pesquisa em Serviço Social, Ano 2, n 3 (Janeiro/ Julho 2001). Brasília: ABEPSS, Grafline, 2001.

KONDER, Leandro. O que é dialética. São Paulo: Editora Brasiliense, $27^{a}$ edição, 1994.

LAVILLE, Christian; DIONNE, Jean. A construção do saber: Manual de metodologia da pesquisa em ciências humanas. Porto Alegre: Editora UFMG e Artmed, 1999.

MADEIRA, Lígia Mari. Presos, prisões e egressos: reflexões acerca de fazer ciência penitenciária. Revista Transdisciplinar de Ciência Penitenciária, $\mathrm{n}^{\circ} 3$ (Janeiro / Dezembro), 2004.

MILLS, C. Wright. A imaginação sociológica. Rio de janeiro: Zahar Editores, 1975.

MINAYO, M. C. de Souza (org.). Ciência, técnica e arte: o desafio da pesquisa social. Petrópolis, RJ: Vozes, 1994.

PASSETTI, Edson. A invenção do crime e a abolição da punição - o discurso abolicionista. Revista Transdisciplinar de Ciência Penitenciária , $n^{\circ} 3$ (Janeiro/ Dezembro), 2004.

PEREIRA, Potyara A. P.. Centralização e exclusão social: duplo entrave à política de assistência social. In Ser Social 3: Exclusão e situação de risco. Revista do programa de pós-graduação em política social do Departamento de Serviço Social da Universidade de Brasília, julho - dezembro de 1998.

PEREIRA, Potyara A. P.. Questão social, Serviço Social e direitos de cidadania. Revista Temporalis. Associação Brasileira de Ensino e Pesquisa em Serviço Social, Ano 2, $\mathrm{n}^{\circ} 3$ (Janeiro/ Julho 2001). Brasília: ABEPSS, Grafline, 2001.

RIBEIRO, Marlene. Exclusão e educação social: conceitos em superfície e fundo. Educação e Sociedade, Scielo Brasil, 2006. 
STOER, Stephen R.; MAGALHÃES, Antônio M.; RODRIGUES, David. Os lugares da exclusão social - um dispositivo de diferenciação pedagógica. São Paulo: Cortez, 2004.

WACQUANT, Loïc. As prisões da Miséria. Rio de Janeiro: Jorge Zahar, 2001.

YAZBECK, Maria Carmelita. Pobreza e exclusão social: expressões da questão social no Brasil. Revista Temporalis. Associação Brasileira de Ensino e Pesquisa em Serviço Social, Ano 2, nº 3 (Janeiro/ Julho 2001). Brasília: ABEPSS, Grafline, 2001.

ZALUAR, Alba. Integração Perversa: pobreza e tráfico de drogas. Rio de Janeiro, Editora FGV, 2004. 


\section{ANEXOS}

\section{1 Anexo A: Roteiro para a entrevista com os educadores:}

Parte 1: Perfil sócio-econômico - perguntas fechadas

1.) Sexo: 1. Masculino ( )

2. Feminino ( )

2.) Idade:

1. ( ) De 19 a 24 anos

2. ( ) De 25 a 30 anos

3. ( ) De 31 a 36 anos

4. ( ) De 37 a 42 anos

5. ( ) De 43 a 48 anos

6. ( ) De 49 a 54 anos

7. ( ) Mais de 54 anos

8. ( ) Sem resposta / Não sabe

3.) Estado civil:

1. ( ) Solteiro

2. ( ) Casado

3. ( ) Separado (desquitado/ divorciado)

4. ( ) Viúvo

5. ( ) Outro: Qual?

6. ( ) Sem resposta / Não sabe

4.) Assinale: Possui filhos? 1. ( ) Sim

2. ( ) Não

Se sim, Quantos?

5.) Assinale - Cor/raça:

1. ( ) Preta

2. ( ) Branca

3. ( ) Parda

4. ( ) Indígena

5. ( ) Amarela

6. ( ) Outra: Qual?

7. ( ) Sem resposta/ Não sabe

6.)Religião: 1. ( ) Católica

2. ( ) Protestante/ Evangélica

3. ( ) Espírita

4. ( ) Religiões afro-brasileiras (umbanda, candomblé, etc)

5. ( ) Outra: Qual?

6. ( ) Sem religião

7. ( ) Sem resposta / Não sabe

7.) Grau de escolaridade: 1. ( ) $2^{\circ} \mathrm{Grau}$ - Curso Normal / Pedagógico

2. ( ) Superior Completo

3. ( ) Superior Incompleto

4. ( ) Pós-graduação:

a. ( ) Especialização. Área: 

b. ( ) Mestrado. Área:

c. ( ) Doutorado. Área:

5. ( ) Sem resposta / Não sabe

8.) Renda familiar ${ }^{16}$ : 1. ( ) Até 3 salários mínimos $(R \$ 1.050,00)$

2. ( ) Mais de 3 a 6 salários mínimos $(\mathrm{R} \$ 2.100,00)$

3. ( ) Mais de 6 a 9 salários mínimos ( $R \$ 3.150,00)$

4. ( ) Mais de 9 a 12 salários mínimos $(R \$ 4.200,00)$

5. ( ) Mais de 12 a 15 salários mínimos $(\mathrm{R} \$ 5.250,00)$

6. ( ) Mais 15 a 18 salários mínimos $(\mathrm{R} \$ 6.300,00)$

7. ( ) Mais de 18 a 21 salários mínimos $(R \$ 7.350,00)$

8. ( ) Mais de 21 a 24 salários mínimos $(\mathrm{R} \$ 8.400,00)$

9. ( ) Mais de 24 salários mínimos

10. ( ) Sem resposta / Não sabe

9.) Tempo de serviço como educador/professor:
1. ( ) Até 2 anos
2. ( ) De 2 a 6 anos
3. ( ) De 6 a 10 anos
4. ( ) De 10 a 14 anos
5. ( ) De 14 a 18 anos
6. ( ) Mais de 18 anos
7. ( ) Sem resposta / Não sabe

10.) Tempo de serviço no presídio: 1. ( ) Até 2 anos

2. ( ) De 2 a 6 anos

3. ( ) De 6 a 10 anos

4. ( ) De 10 a 14 anos

5. ( ) De 14 a 18 anos

6. ( ) Mais de 18 anos

7. ( ) Sem resposta / Não sabe

11.) Local de moradia no DF /Entorno:

Parte 2: Perfil político-ideológico - perguntas fechadas

12.) O Sr(a) participa ou já participou de alguma associação comunitária (associação de moradores, prefeitura comunitária, clube esportivo, etc)?
1. ( ) Sim
2. ( ) Não

13.) Se sim:

Qual?

Por que?

14.) O Sr(a) participa ou já participou de algum movimento social (negros, mulheres, ambientalista, homossexuais, etc)?
1. ( ) Sim
2.( ) Não

\section{5.) Se sim:}

${ }^{16}$ Valor em abril/2007: R\$ 350,00 
Qual?

Por que?

16.) o $\operatorname{Sr}(a)$ é militante de algum partido político?

1.( ) Sim

2.( ) Não

17.) Se sim: Qual?

1.( ) PMDB
2.( ) PT
3.( ) PDT
4.( ) PSDB
5.( ) PC do B
6.( ) PV
7.( ) PSB
8.( ) PCB
9.( ) PSC

10.( ) PTB

11.( ) PCO

12.( ) PSTU

13.( ) PPS

14.( ) PFL

15.( ) PSOL

16.( ) Outro: Qual?

17.( ) Sem resposta / Não sabe

Parte 3: Democracia e cidadania - perguntas fechadas e abertas

18.) O que significa para o $\operatorname{Sr}(a)$ ser cidadão no Brasil?

19.) O que o sr(a) conhece os seus direitos de cidadão?

1.( ) Sim

2.( ) Não

20.) Se sim: Quais são esses direitos?

21.) A educação no presídio está voltada para formar cidadãos/cidadãs/

1.( ) Sim

Por que?

2.( )Não

22.) Que atividades são desenvolvidas, tendo em vista a formação cidadania?

23.) O que significa viver em uma sociedade democrática para o $\operatorname{sr}(a)$ ?

24.) São desenvolvidas práticas democráticas no setor da educação no presídio? (exemplo: se os detentos opinam sobre o conteúdo programático, se contribuem no plano de curso, etc)
1. ( ) Sim
2. ( ) Não

Por que?

25.) Se sim: Quais?

\section{Parte 4: Educação e emancipação social- perguntas abertas}

26.) Na sua opinião, os alunos/detentos são reconhecidos como sujeitos de direitos?

1.( ) Sim

2.( ) Não

Por que?

27.) Na sua opinião, o ensino no presídio tem por objetivo a promoção de uma cidadania ativa e participativa?

1. ( ) Sim

2. ( ) Não

Por que? 
28.) $\mathrm{N}$ sua opinião, qual deve ser a postura de um professor que favoreça o reconhecimento da igualdade de direitos humanos e o respeito às diferenças?

29.)O sr(a) acredita que a educação no presídio tem sido eficaz?

1.( ) Sim

2.( ) Não

Como?

Por que?

30.) Na sua opinião, o que precisa mudar para ser mais eficaz?

31.) Como educador(a), já participou de alguma capacitação?
1.( ) Sim
2.( ) Não

32.) Se sim: Há quanto tempo?

33.) $\mathrm{Sr}(\mathrm{a})$ conhece a metodologia de Paulo Freire?
1.( ) Sim
2.( ) Não

34.) Se sim: O sr(a) utiliza em seu plano de curso?

35.) O Sr(a) acredita que a educação participa para a emancipação dos sujeitos sociais?

1.( ) Sim

2. ( ) Não

Como? 


\subsection{Anexo B: roteiro para entrevista com os educandos}

Parte 1: Perfil sócio-econômico - perguntas fechadas

1.) Sexo: 1. Masculino ( ) 2. Feminino ( )

2.) Idade: $\quad$ 1. ( ) De 19 a 24 anos

2. ( ) De 25 a 30 anos

3. ( ) De 31 a 36 anos

4. ( ) De 37 a 42 anos

5. ( ) De 43 a 48 anos

6. ( ) De 49 a 54 anos

7. ( ) Mais de 54 anos

8. ( ) Sem resposta / Não sabe

3.) Estado civil:

1. ( ) Solteiro

2. ( ) Casado

3. ( ) Separado (desquitado/ divorciado)

4. ( ) Viúvo

5. ( ) Outro: Qual?

6. ( ) Sem resposta / Não sabe

4.) Assinale: Possui filhos? 1. ( ) Sim

2. ( ) Não

Se sim, Quantos?

5.) Assinale - Cor/raça:

1. ( ) Preta

2. ( ) Branca

3. ( ) Parda

4. ( ) Indígena

5. ( ) Amarela

6. ( ) Outra: Qual?

7. ( ) Sem resposta/ Não sabe

6.)Religião: 1. ( ) Católica

2. ( ) Protestante/ Evangélica 
3. ( ) Espírita

4. ( ) Religiões afro-brasileiras (umbanda, candomblé, etc)

5. ( ) Outra: Qual?

6. ( ) Sem religião

7. ( ) Sem resposta / Não sabe

7.) Grau de escolaridade: 1. ( ) $1^{\circ} \mathrm{Grau}$ Incompleto

2. ( ) $1^{\circ}$ Grau Completo

3. ( ) $2^{\circ} \mathrm{Grau}$ Incompleto

4. ( ) $2^{\circ}$ Grau Completo

5. ( ) Superior Incompleto

6. ( ) Superior completo (ou concluindo)

7. ( ) Sem resposta / Não sabe

8.) Renda familiar" ${ }^{17}$ : 1. ( ) Salário mínimo ( $\left.R \$ 350,00\right)$

2. ( ) Dois salários mínimos $(\mathrm{R} \$ 700,00)$

3. ( ) Três salários mínimos ( $R \$ 1.050,00)$

4. ( ) Mais de 3 a 6 salários mínimos $(R \$ 2.100,00)$

5. ( ) Mais de 6 a 9 salários mínimos ( $R \$ 3.150,00)$

6. ( ) Mais de 9 a 12 salários mínimos ( $R \$ 4.200,00)$

7. ( ) Mais de 12 a 15 salários mínimos ( $R \$ 5.250,00)$

8. ( ) Sem resposta / Não sabe

9.) Local de moradia no DF /Entorno:

10.) Exercia alguma atividade profissional antes de ser condenado?
1. ( ) Sim
2. ( ) Não

11.) Se sim: Qual atividade?

12.) Situação processual: Quanto tempo preso?1. ( ) Até 6 meses

2. ( ) De 6 meses a 1 ano

3. ( ) De 1 ano a 2 anos

4. ( ) De 2 anos a 3 anos

5. ( ) De 3 anos a 4 anos

6. ( ) Mais de 4 anos

7. ( ) Sem resposta / Não sabe

\footnotetext{
${ }^{17}$ Valor em abril/2007: R\$ 350,00
} 
13.) Enquanto preso, o Sr. freqüentou a escola?
1. ( ) Sim
2. ( ) Não

14.) Se não: Por que? Qual o impedimento? O que desmotivou?

15.) Se sim: Quanto tempo freqüentou a escola? Chegou a graduação?

Parte 2: Democracia e cidadania - perguntas fechadas e abertas

16.) O que significa para o $\mathrm{Sr}(\mathrm{a})$ ser cidadão no Brasil?

17.) O que o sr(a) conhece os seus direitos de cidadão?
1.( ) Sim
2.( ) Não

18.) Se sim: Quais são esses direitos?

19.) O que significa viver em uma sociedade democrática para o $\operatorname{sr}(a)$ ?

20.) O que significa ser livre?

Parte 3: Educação e emancipação social- perguntas abertas (para os que freqüentaram a escola na prisão)

21.) Na sua opinião, como aluno você se sentia respeitado, visto como um sujeito de direitos?
1.( ) Sim
2.( ) Não

Comente a respeito:

22.) Na sua opinião, o Sr. acredita que, hoje, é um cidadão ativo e participativo devido à educação?
1. ( ) Sim
2. ( ) Não

Comente a respeito:

23.) Como era o relacionamento com os professores?

24.)O sr(a) acredita que a educação no presídio foi eficaz, dentro do que esperava, ou seja, você alcançou seus objetivos através da educação?
1.( ) Sim
2.( ) Não

Como? 
25.) Na sua opinião, o que a educação precisa mudar para ser mais eficaz?

26.) Gostaria de fazer algum comentário: 
7. Anexo C

http://www.mj.gov.br/depen/sistema_informacao.htm 